\title{
Geostories: A New Landscape-Ring between Italy, Slovenia and Austria
}

\begin{abstract}
By Adriano Venudo*
The research investigates the border between Italy, Slovenia and Austria which is part of a wider system, on a continental scale: the European Green Belt which stood on the border of the "iron curtain". This research uncovered a "landscape-ring", a large cross-border ring, which contains a sort of "border region" that no one had yet identified. It is an autonomous entity, although belonging to the three states. The "landscape-ring" is made up of pieces of existing infrastructure belonging to other systems, but which represent, within the ring around the border, an "important" new infrastructure serving the territory. It also represents a functional unit (landscape, environmental, settlement, community), a perception system, in a few words an entire structural unit for the border region.
\end{abstract}

Keywords: Landscape, infrastructure, mobile border, mutation ecology, Italy, Austria, Slovenia

\section{Introduction}

\section{Border as Landscape}

This article summarises the findings of a research conducted by the author in collaboration with Giovanni Fraziano, Thomas Bisiani, Luigi Di Dato, Claudio Menino, Valentina Rodani, and Marko Verri, teachers of the Univeristy of Trieste and Špela Hudnik, visiting professor and teacher at University of Lubljana. The research focused on the "big change" ongoing along the Italian, Austrian and Slovenian border, following the geo-political developments of the last 20 years.

The research area is set along the Italian, Slovenian and Austrian border, in north-eastern Italy, from the mountains of Carnic Alps to the Adriatic Sea shore. Here, the national border runs for $180 \mathrm{~km}$ and above an extended area of $7000 \mathrm{~km}^{2}$ (Figure 1), which has been also included in the study site, and represents a "landscape-unit" (Figure 4), stratified with history and traditions of the communities that inhabit it (rhythm and fluxes), and represents a territory with a unique potential for the development of new projects (Geographies).

The research thesis finds that the capacity of geography does re-write and inform always new architectonic languages; vice versa architecture -if considered from the geographer's point of view- re-shapes periodically, through scales, history of geography and its very representation, always new relations, arrangements, original texts that are the result of territorial processes (Figures 5-6)

${ }^{*}$ Researcher, University of Trieste, Italy. 
(Albrecht and Benevolo 1992). That is, in Corboz's (1985) words, the codification of the palimpsest. The research had these main objectives:

- Elaborating a new interpretation of architecture and landscapes, shaped on the geographic matrix of the border, in the aforementioned cross-border region.

- Developing a cross-cutting dialogue on territorial models shaped on the edge between geography and architecture.

- Designing landscape and infrastructure project proposals for cross border areas within a cross border cooperation mindset.

These objectives have made it possible to identify a new "territorial figure"; a new cross-border geography, the landscape-ring between Italy, Slovenia and Austria (Figures 2-4).

Figure 1. Extension of the National Border at the Base of the New "LandscapeRing" between Italy, Slovenia and Austria

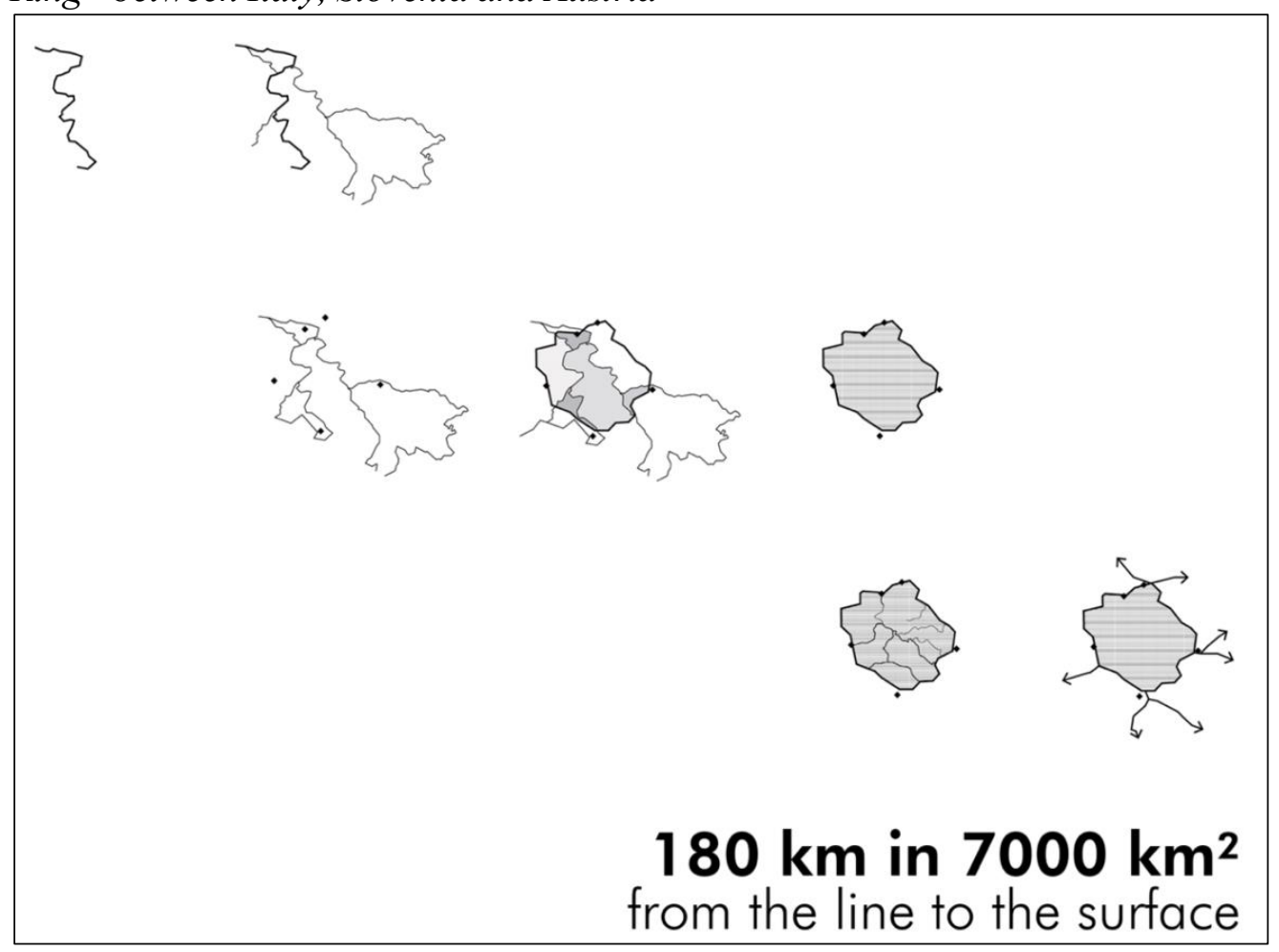

Source: Elaboration by Monica Bidoli, Matteo Savron, Elwira Wojcicka. 
Figure 2. Recognition of the "Landscape-Ring", Contextualization and Territorial Insertion in the Alps-Adriatic Macro-Region

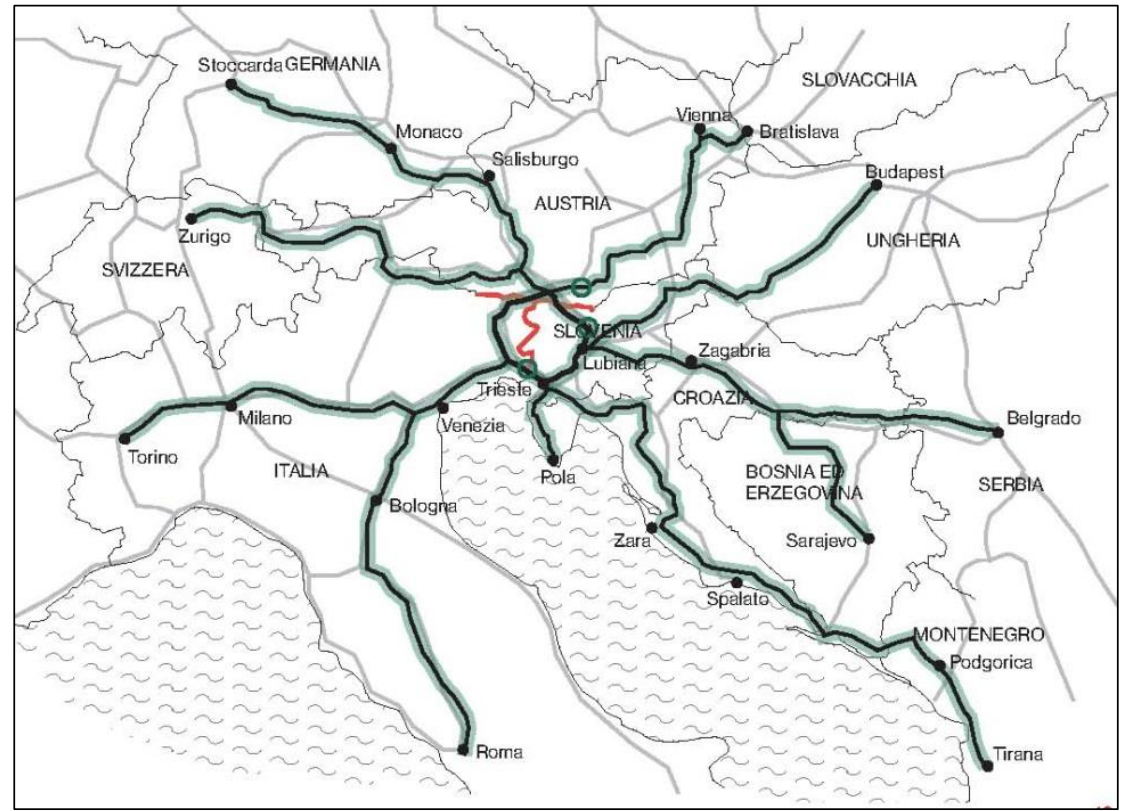

Source: Elaboration by Monica Bidoli, Matteo Savron, Elwira Wojcicka.

Figure 3. European Macro Region of Alpe-Adria and Localization of New "Landscape-Ring" between Italy, Slovenia and Austria

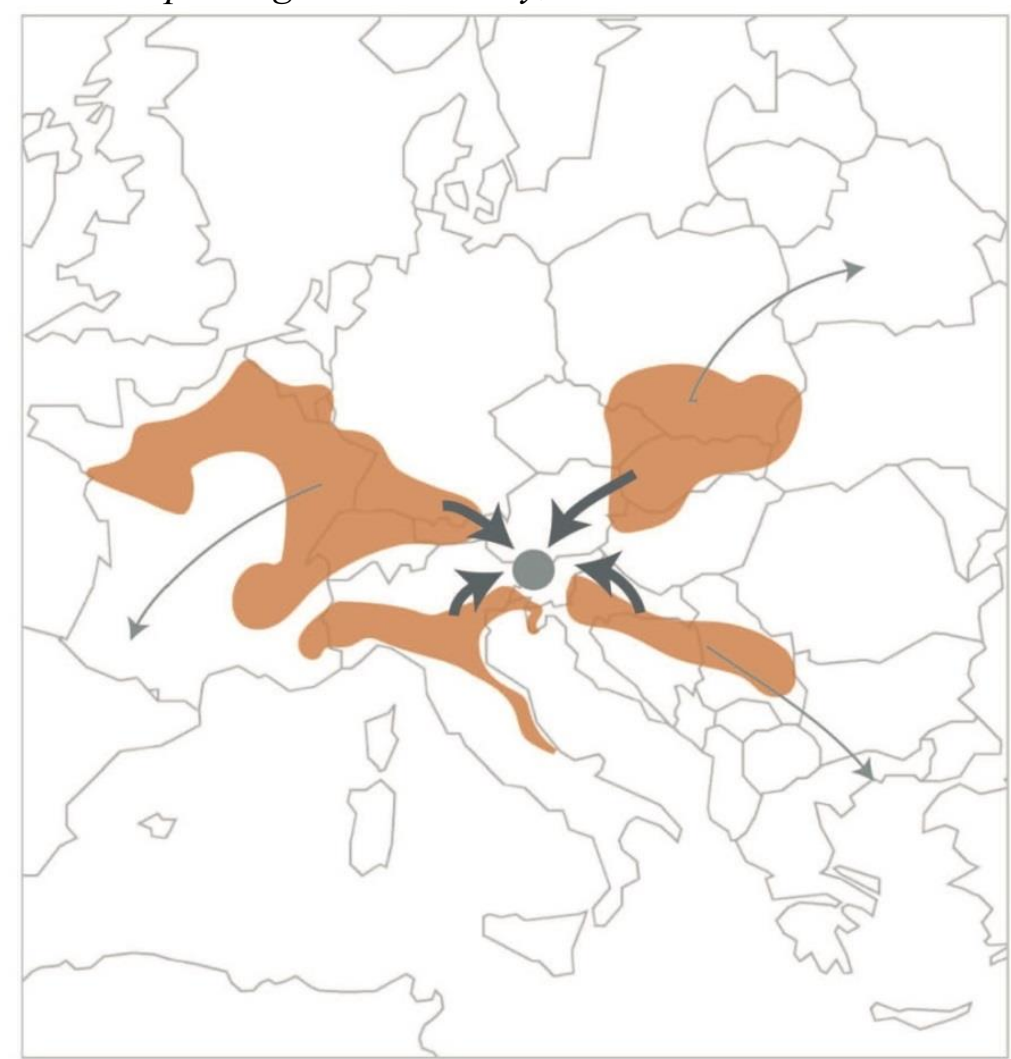

Source: Elaboration by Giulia Piacente, Stela Guni, Vittoria Umani. 
Figure 4. "Landscape-Ring” between Italy, Slovenia and Austria
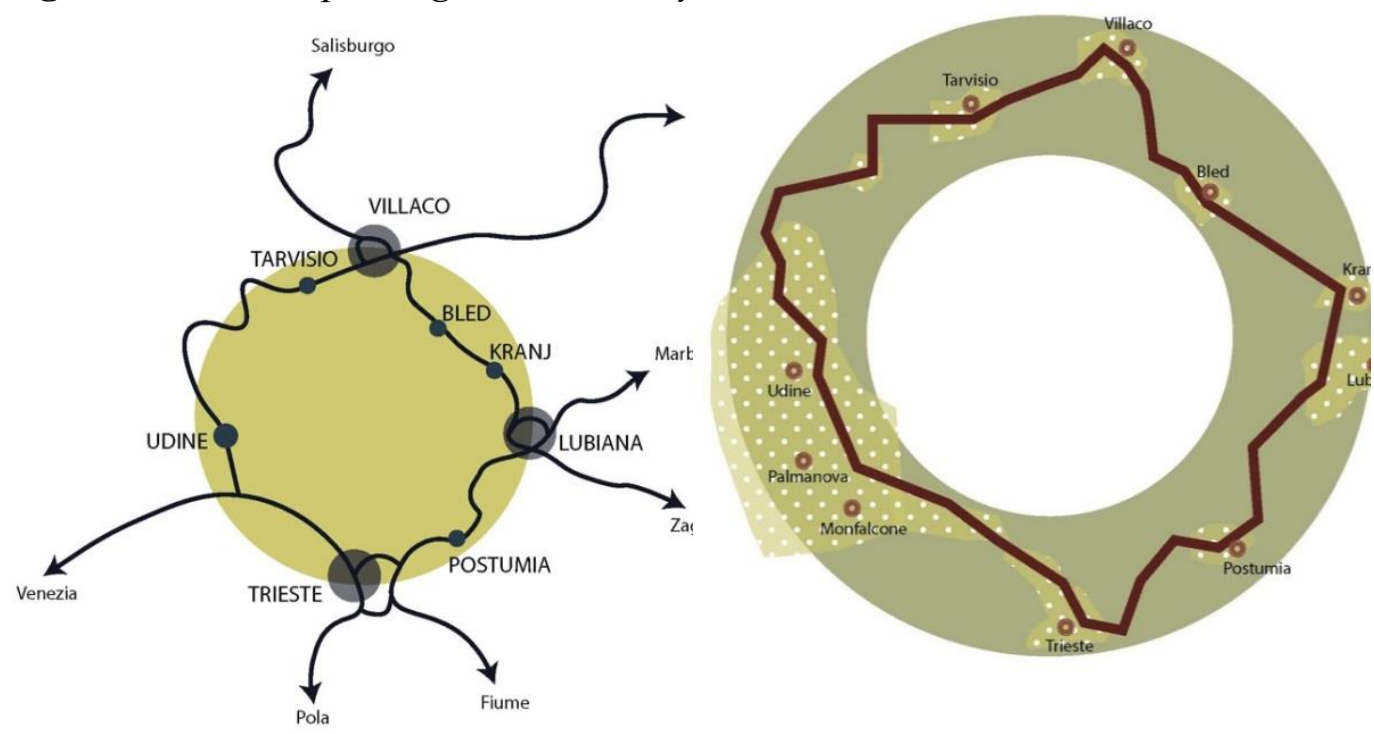

Source: Elaboration by Giulia Piacente, Stela Guni, Vittoria Umani.

Figure 5. Space-Time Map of the Macro-Region before and after the Operation of the "Landscape-Ring"

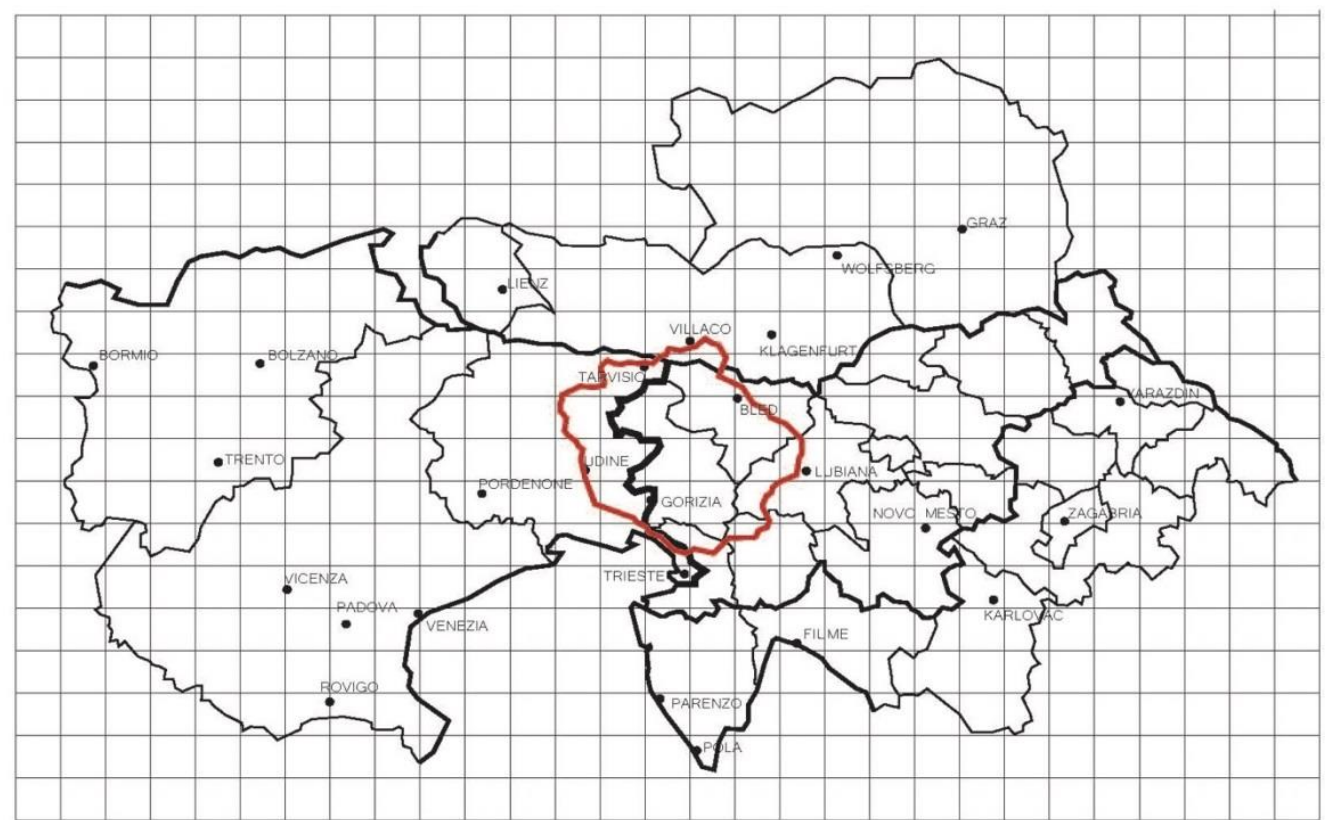

Source: Elaboration by Monica Bidoli, Matteo Savron, Elwira Wojcicka. 
Figure 6. Space-Time Map of the Macro-Region before and after the Operation of the "Landscape-Ring"

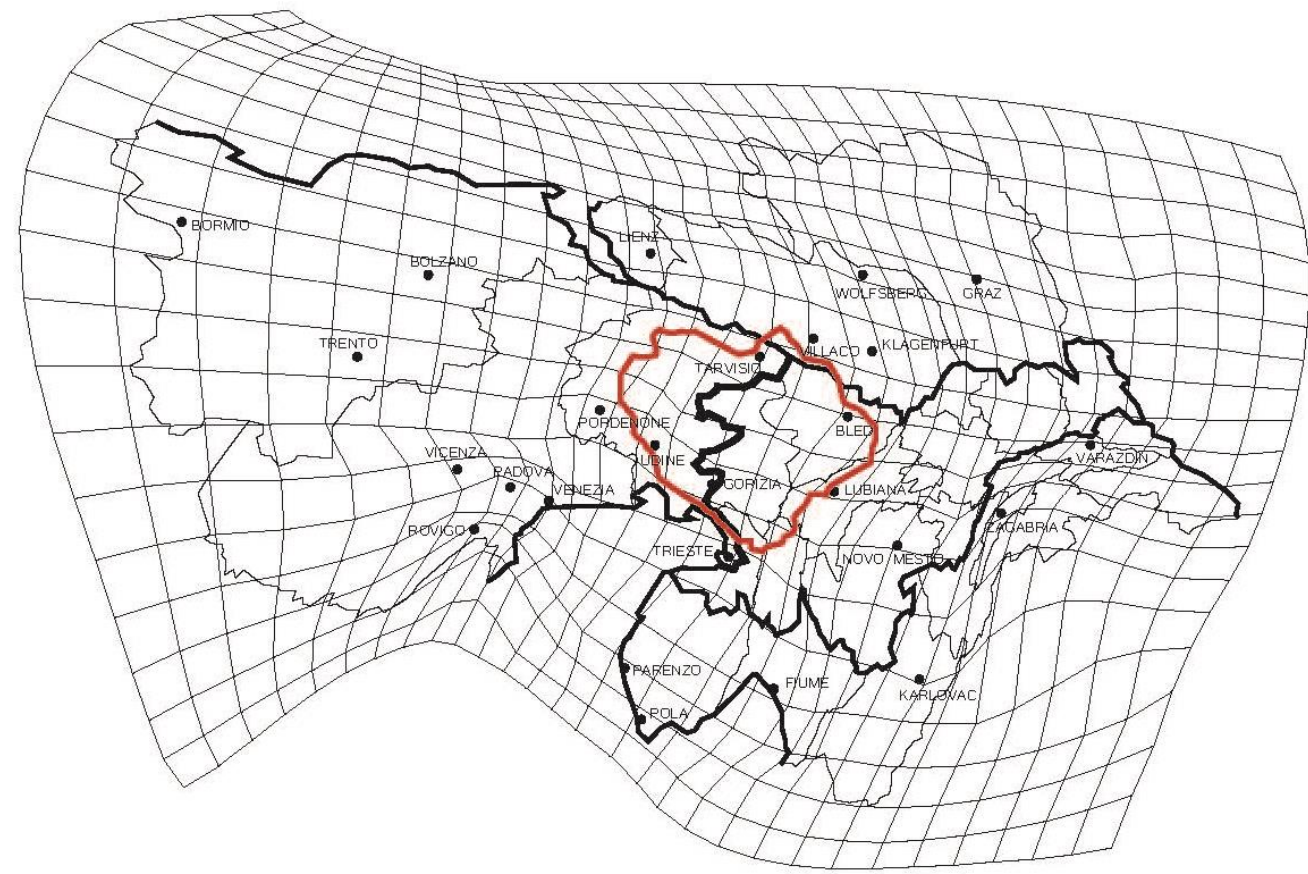

Source: Elaboration by Monica Bidoli, Matteo Savron, Elwira Wojcicka.

The border at stake, for known historical reasons (Bufon 1990) and, more recently, due to geo-morphological changes (i.e., it runs along the alpine region, where high altitude glaciers are currently shrinking due to climate change and fastly re-shaping the morphology of the land), is defined as a "moving" border. The alpine area moves along the movement of the glaciers (Figures 7-9), and so does the border, thus yearly modifying, even so slightly (Ferrari et al. 2018), the official geo-political maps (Figures 10-12).

To address this issue, the States along the Alpine chain (including Austria, Slovenia and Italy) have thus officially codified the concept of "moving border" (Biondi 1995), and that of "instability of geological elements", traditionally considered unchanging. This leads to the scientific acknowledgement of the instability of natural borders, one of the pillars at the base of the concept of national territory. So, will climate change reshape, beside landscape structure, also the identity of these areas (Basso 2010)?

We have used the concept of "border as landscape" elaborated by Basso (2010) which has become a key to identifying the geographical areas of this crossborder region, and we structured the research in four steps, through survey and project tools, words and media for geographic elaboration, looking for the subtle connection between word and content, mapping and structure, territory and environment, landscape and place, shape and image.

The studies of the 11 working groups were all put together to shape the new landscape's mosaic. Eleven visions were developed, each imagining a new geography of the border. Together, they re-designed a new morphology of the limes (Figures 7-11), palimpsest of a multiethnic community where the remains of 
the history of places can write a new story between geography, landscape and architecture. These eleven visions in turn become the project making material for the overall re-shaping of landscape. The geographer Giorgio Valussi, between the end of 1950s and mid 1965s, conducted a series of studies on Carsic landscapes (Vallussi 1963), both in Italy and Slovenia, leading him to formulate the theory of the "geography of the border", finding its roots in the continuous changes within landscapes (Bufon 1994).

Figures 7-9. Mobile Border Processing Diagrams: The Boundary in relation to the Valleys, Mountains and Glaciers

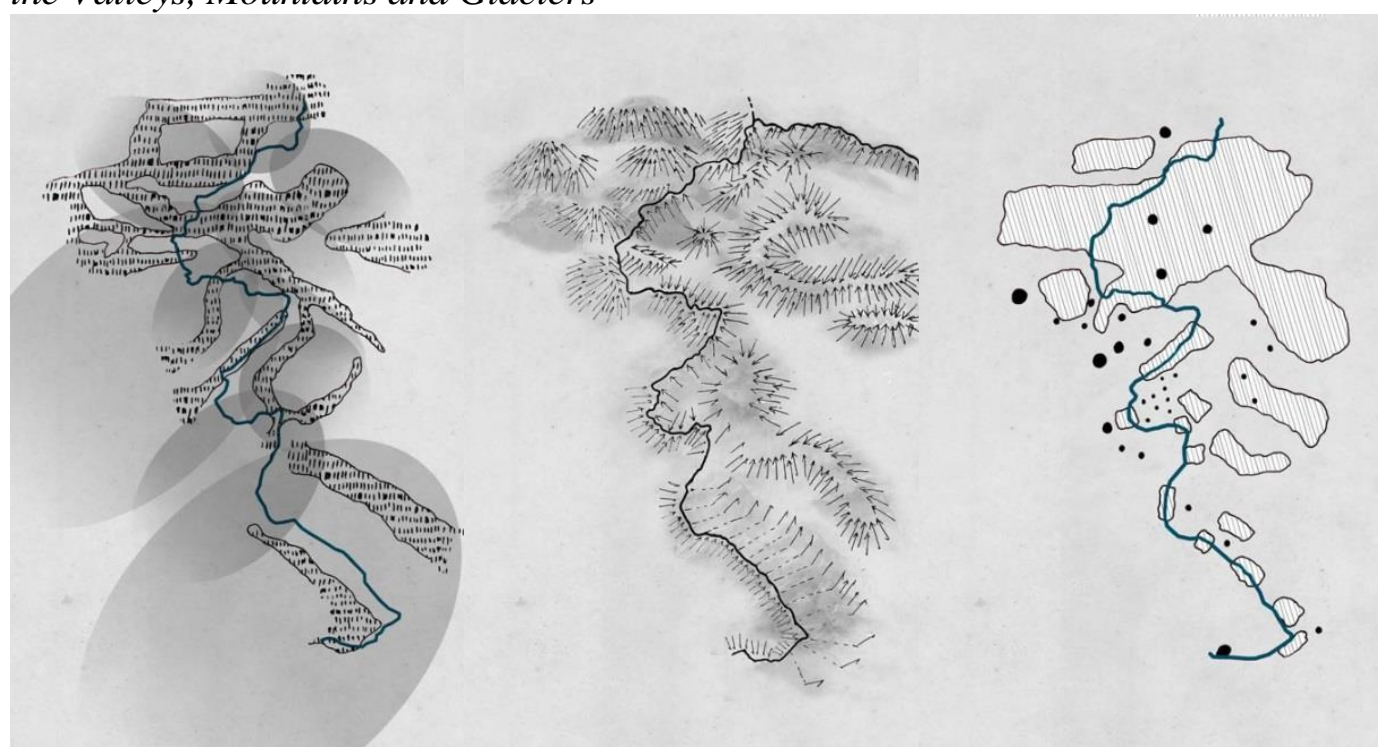

Source: Elaboration by Angela Bertoni, Lorenzo Kratter, Giada Lesizza.

Figure 10. Satellite Image of the Border between Italy, Slovenia and Austria (Regions of Friuli Venezia Giulia, Carinzia, Goriška, Gorenjsk and Obalno Kraska)

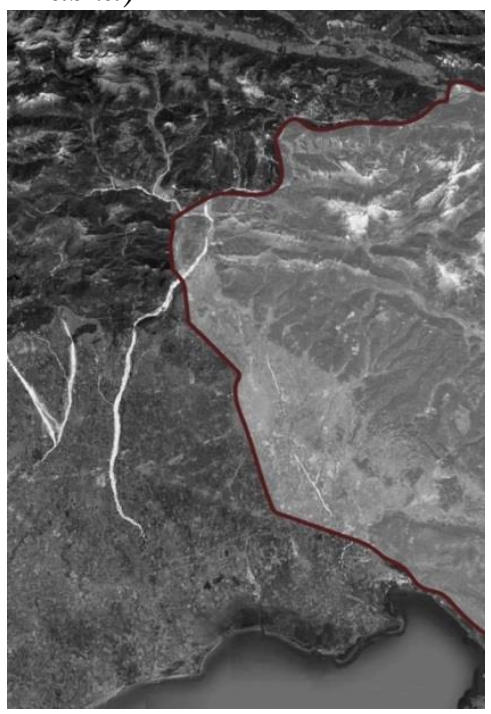

Source: Elaboration by Giulia Piacente, Stela Guni, Vittoria Umani. 
Figure 11. Morphology of Limes: The Environmental, Infrastructural and Settlement Systems of the Border Region

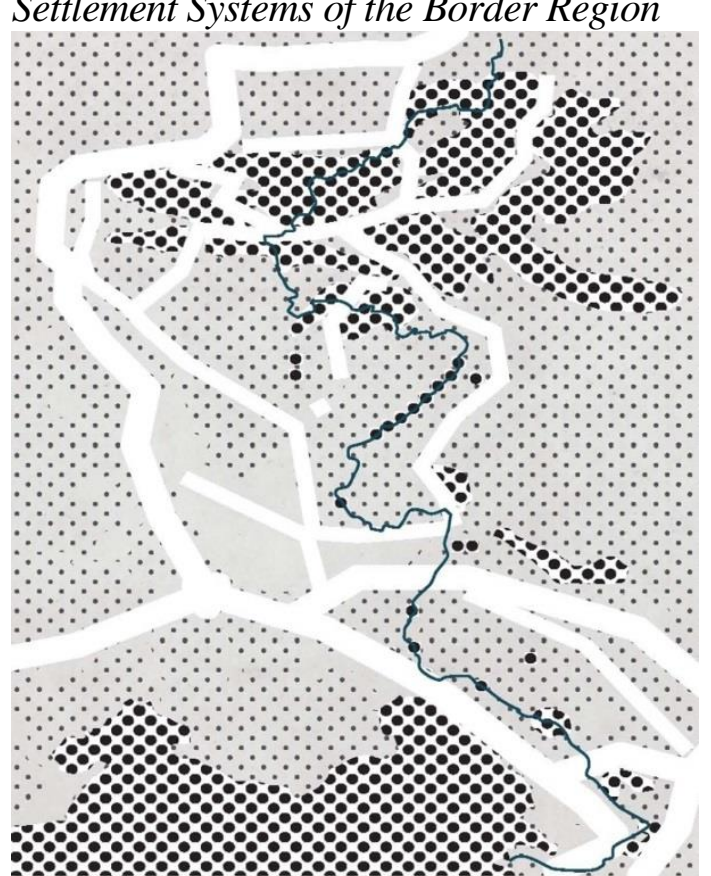

Source: Elaboration by Angela Bertoni, Lorenzo Kratter, Giada Lesizza.

Figure 12. Team of Researchers that Map the Movements of the Border on the Glaciers between Italy, Slovenia and Austria

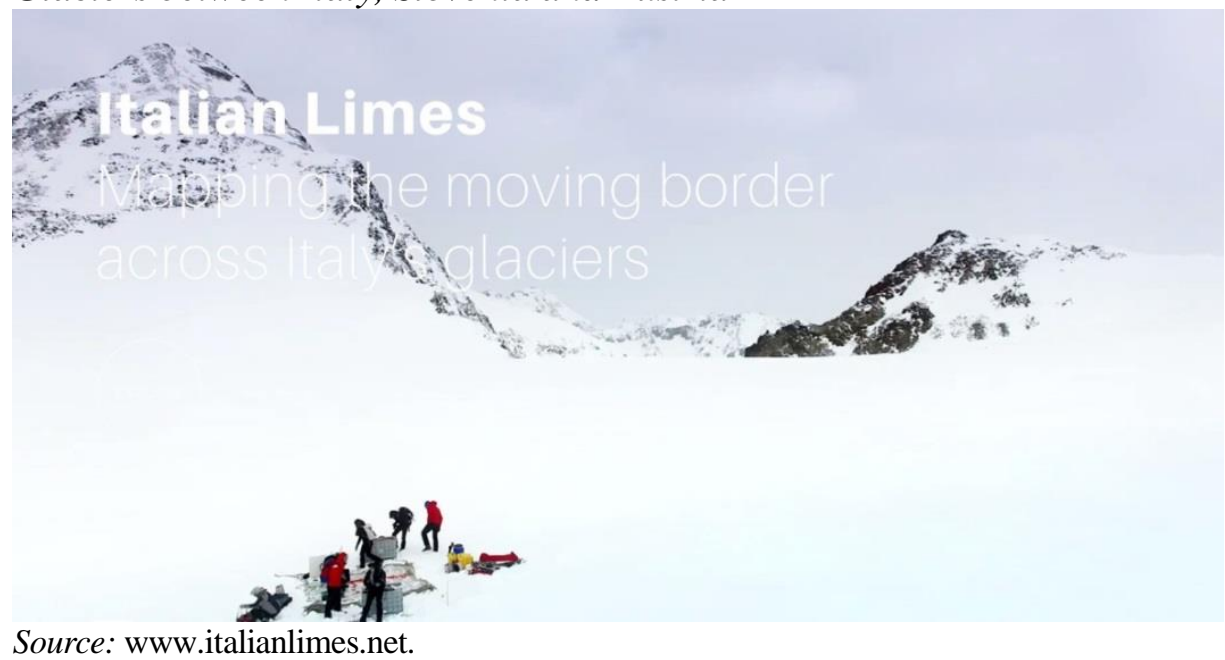

\section{Tools and Methodology}

\section{From Immago Limes, to New Geographies}

The research work was organized into four macro phases, which developed from analysis and data collection, to the development of synthesis and interpretation models, to arrive at the first indications of the masterplan: 
The first phase, immago limes (Figure 14), implied an analytical reconstruction of the territory's structure, functioning, through the analysis of landscapes, systems (nature, settlements, infrastructures, etc.), fluxes, relations, historical evolution, current ongoing dynamics, obstacles/potential, through data gathering.

During the second phase, visions, data were interpreted, summary models were elaborated, extended areas were identified for each segment of the border line, indicators were chosen, ecologies were defined, and thematisation was carried out through "narration".

The third phase, frammenti (fragments), implied the development of metaprojects concerning the overall thematisation and the identified obstacles/potential (Figure 13). These meta projects allowed for the focus on specific themes and places for the actual project.

During the fourth and last phase, geographies, all information, analytic and project elaborations and experiences were put together (Figures 15-16) to elaborate the final deliverables: eleven ecologies, maps of change, border landscapes, the cross border ring, the city of the border and the new geography of the border.

Figure 13. Image of the Italy and Slovenia Border on the Trieste Karst

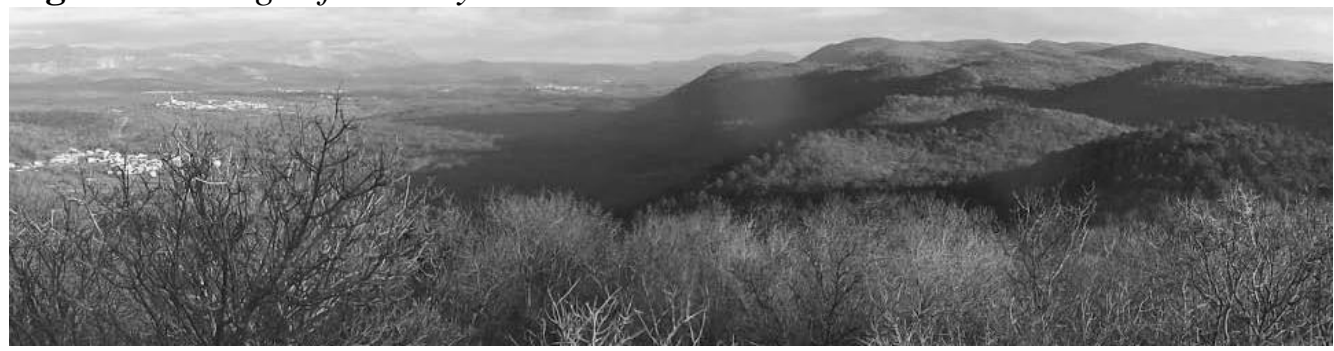

Source: Elaboration by Sofia Artico, Federica Ferrigno, Lara Slavec.

Figure 14. Immago Limes: Interpretation of the Structural Components and Perceptual Characteristics of the Border

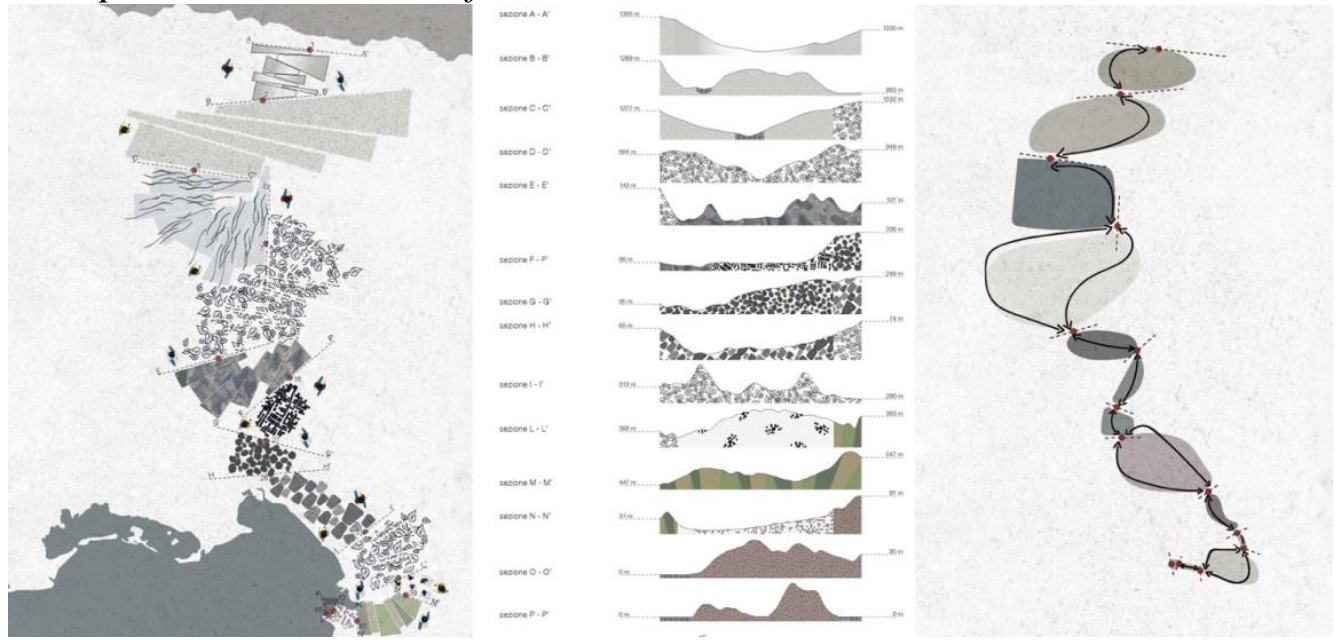

Source: Elaboration by Giorgio Conforto, Eleonora Di Stefano, Debora Paulin. 
Figures 15-16. Pre-Geography of the Border Redesigned on the Basis of the Permeability of the Border-Crossings

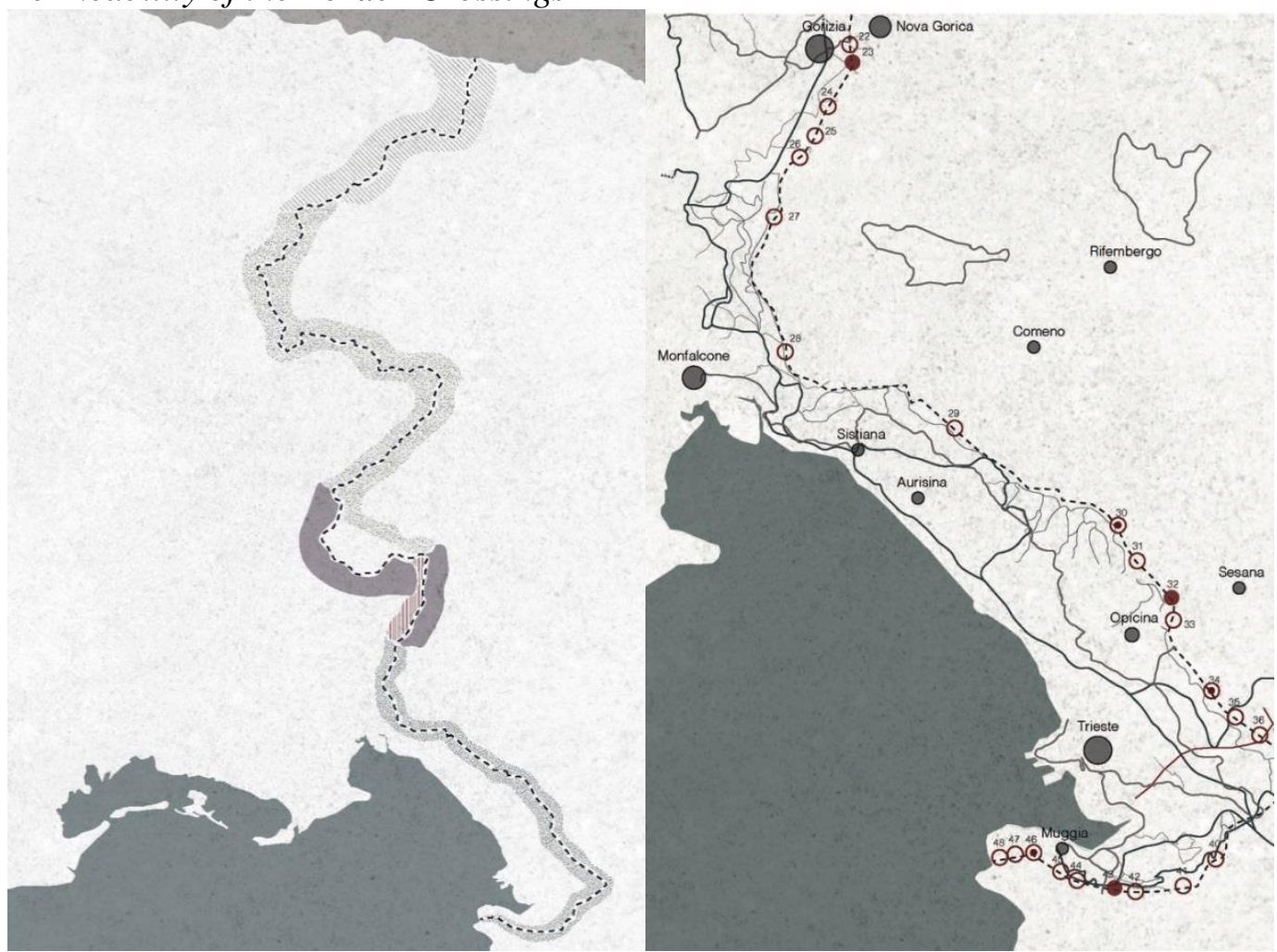

Source: Elaboration by Giorgio Conforto, Eleonora Di Stefano, Debora Paulin.

\section{Discussion}

\section{Mapping the Change}

The structure of the territory, the stratification of the landscape and the measurement of social and economic transformations are the basis of the proposal for this "new geography of the border". A series of thematic maps have been developed which consider all these areas of investigation as indicators of the structural value of the "mobile border". The result obtained is a set of representations, with a visual approach to human geography (Greiner et al. 2012), which are the index of the relationship between territorial systems and dynamics of functioning (linked precisely to the border). In order to map the ecologies of communities (Dematteis 1991), eleven characters were chosen to represent the layering of the territory and of its landscapes, and their perspectives were used for mapping changes, as key indicators of the complex ongoing transformations, especially with respect to the ethnic mosaic, the true origin of this complexity, concept theorized by La Cecla in "What are borders for?" (La Cecla 1996). From this book by La Cecla the idea was born to visualize "the geography of the characters" of the border and to edit anthropogeographic maps, which could represent the ecologies of change. These characters are: Inhabitant; The poet; The 
onlooker; The artist; The commuter; The unemployed; The priest; The collector; The miner; The traveler; The pilgrim.

The representation of the ecologies of change (Dematteis and Ferlaino 2003) is embodied in eleven cartographies that together show the moving dimension of the border space (Figure 17). These are: 1. Map of resonance; 2. Map of poetic actions; 3. Map of landscapes; 4. Map of intersections; 5. Map of the arcipelago; 6. Map of stratigraphy; 7. Map of memories; 8. Map of paths; 9 Map of diagenesis; 10. Map of fluxes; 11. Map of exceptions.

Figure 17. Ecologies of Change Map. The Summary Maps of the 11 Ecologies of Change are: 1. Map of Resonance (Lorenzo Kratter, Giada Lesizza, Angela Bertoni); 2. Map of Poetic Actions (Virgini Fabbro, Silvia Musini, Arianna Santarsiero); 3. Map of Landscapes (Giorgio Conforto, Eleonora Di Stefano, Debora Paulin); 4. Map of Intersections (Sofia Artico, Federica Ferrigno, Lara Slavec); 5. Map of the Archipelago (Stela Guni, Giulia Piacente, Giulia Toscano, Vittoria Umani); 6. Map of Stratigraphy (Vlad Maricel Martinas, Semir Skenderovic); 7. Map of Memories (Ivan Bello Ivan, Jesku Franklind); 8. Map of paths (Giacomo Caporale); 9 Map of Diagenesis (Lorna Mattias, Michela Contin, Devescovi Valentina); 10. Map of Fluxes (Matteo Ros, Milisav Stankovic, Enrico Vidulich); 11. Map of Exceptions (Matteo Savron, Elwira Wojcicka, Monica Bidoli)
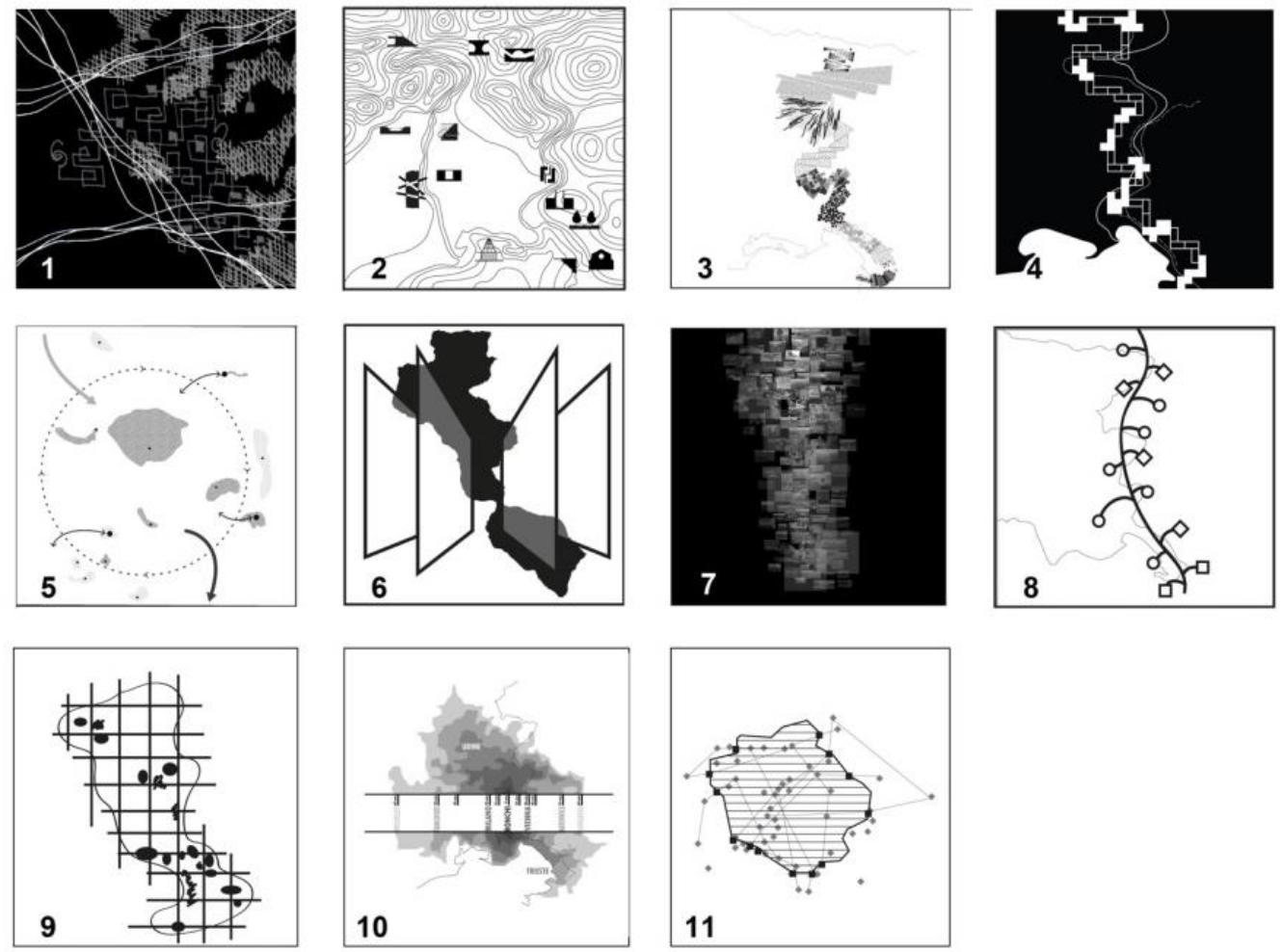

This constant change of the territory, that could apparently seem an issue for territorial identity, represents indeed an element of unity (physical, morphologic, economic) of landscape and territory, etc.) and the main character of the identity of the cross-border region (Zanini 1997). This is indeed the reason behind the attempt 
to elaborate a "new own geography", based on the paradigm of mutation itself (Dematteis 1996).

Starting from the shape of the cross-border ring, different themes were investigated:

1. Dimension, perception, stratifications.

2. Re-reading, narrations and landscapes, literature and poetry of the territory.

3. Landscape unity, natural macrosystems, environment, vegetational structures, panoramic views.

4. Art and nature.

5. Systems, infrastructures, territorial settlements, heritage system.

6. Abandonment.

7. Memory and territorial symbology.

8. Backbone and infrastructure.

9. Morphology, lithology and extraction plants.

10. European corridors and regional networks.

11. Slow landscapes, paths, places of worship.

The analytical reading was elaborated with two visions in mind:

1. A taxonomy chart of landscapes (sound, imagination, perception, art, mankind, habits, industrial archeology, memory, movement, earth, speed, spirituality).

2. A new "map" allowing for a new interpretation of the border extended area as a whole territory, with its own geography.

The eleven visions elaborated (thematisms) codify the layers of the crossborder landscape, with the aim to develop:

1. Tools allowing for the interpretation of the ongoing change.

2. A "pre-geography of the border", aimed at orienting the urban and landscape planning within the cross border cooperation framework among Italy, Slovenia and Austria.

\section{Hypothesis}

\section{A New Landscape-Ring between Italy, Slovenia and Austria}

The experimentation of new tools and methodologies for the study of the landscape geography's was a further objective, correlated to the main one of this research (study of the landscape-ring). The experimentation also concerned the methods of data collection and the use of the appropriate tools, languages, and finally the construction of the narrative/description (geographic). The expected results aimed at defining a new geography of the border, the results obtained stopped a little earlier, then between a geography and a pre-geography. Pre- 
geography is a figure born out of uncoded and unstable systems. Precisely by means of this informal condition, the approach to pre-geography manages to bring out often illegible structures and systems. Constellations are the most significant example of what could be a "pre-geography".

In the end it was decided to maintain an incomplete, pre-geographic layout for the open, generative character, as if they were a guideline, because they will probably be more useful and effective than a configuration concluded or closed for programming, mediation and cross-border cooperation activities.

The case study dealt with an area that stretches along the border of three states, five regions, involving numerous landscapes from the mountains to the sea. Eventually, putting together the eleven visions elaborated by the working groups, an extended area of about $7000 \mathrm{mk}^{2}$ was identified as the actual "region of the border" (Figures 18-19), in particular infrastructure and landscape. This regions lays within a bigger cross-border ring whose shape is defined by pieces of existing infrastructures, already identified as territorial frame in the studies of Luciano Di Sopra on the Friulian urban structure (Di Sopra 1967), belonging to other systems, but representing, within the ring around the border, a new important infrastructure serving the territory. It also represents a functional unity, an autonomous system, a whole structural unity for the region of the border. The infrastructures used for this new re-shaping of the functionalities of the territory are highways A4 and A23 in Italy, freeway E61 and E652 in Slovenia and highways A2 in Austria (Figures 2023). This ring will allow to build new internal and above all external territorial relationships, in particular with the whole of central Europe (Figures 21-22). It exploits an existing condition (Figures 23-25) to encourage mobility and more widespread connections for the whole "border region". We have recognized numerous territorial systems within this ring, which are configured as constellations (Figure 25), which give strength and unity to a sort of "new border region".

Now if we reinterpret this "border territory" according to this ring structure, we will be able to identify an original constellation of landscapes (Figure 25), natural systems, small villages, linear settlements and cities. What before appeared to us as a local fragmentation and banal settlement dispersion, by means of our landscape-ring (new interpretation) now takes on a local, national, transnational configuration: a huge "city-border". It is an infrastructure that already exists, and that already partially functions as an "infrastructure-ring" around the border. Now few resources would be needed to make it function as a cross-border territorial system. Later, according to a time schedule, it can also be used as a starting point for cross-border urban, landscape and territorial development (Figure 24). 
Figure 18. Thematic Map of the Border Region "Discovered" within the Landscape-Ring. The "Sprawltown of the Border" is Extended within a Kind of Large Ring that Crosses the Border between Italy, Slovenia and Austria

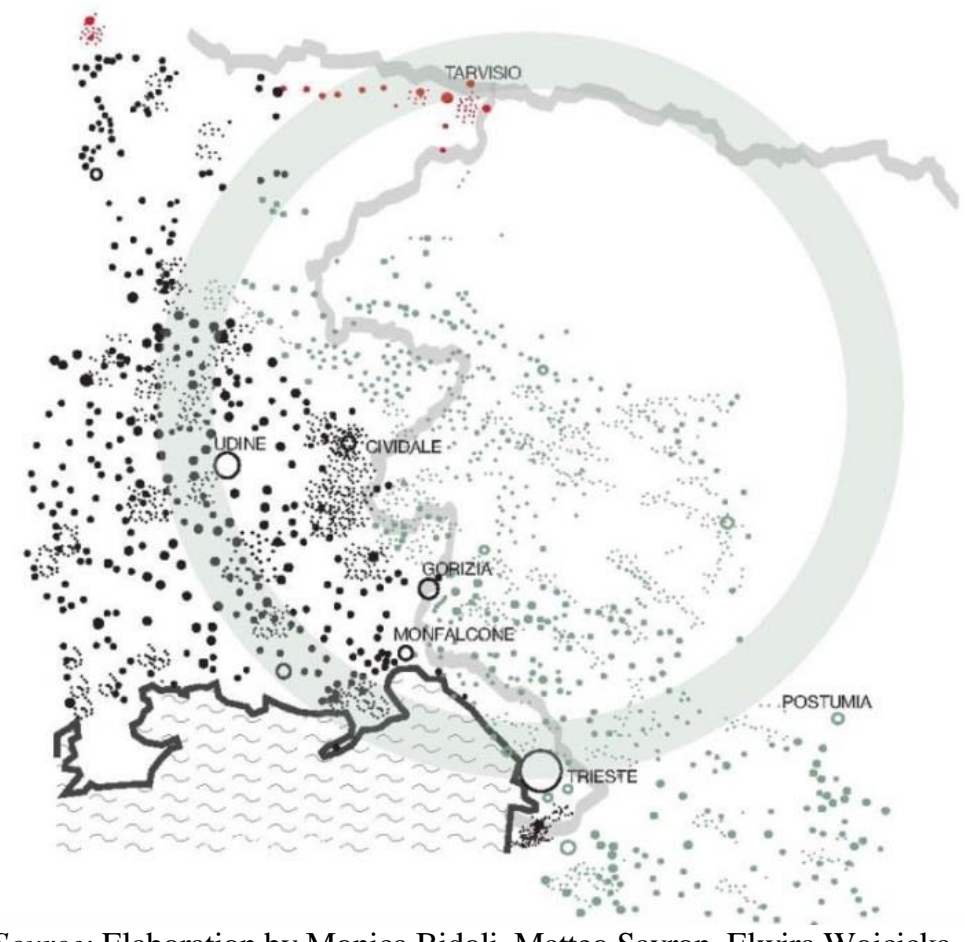

Source: Elaboration by Monica Bidoli, Matteo Savron, Elwira Wojcicka.

Figure 19. Panoptic Diagram Showing the Edges and Landscapes of the Landscape-Ring from the Road

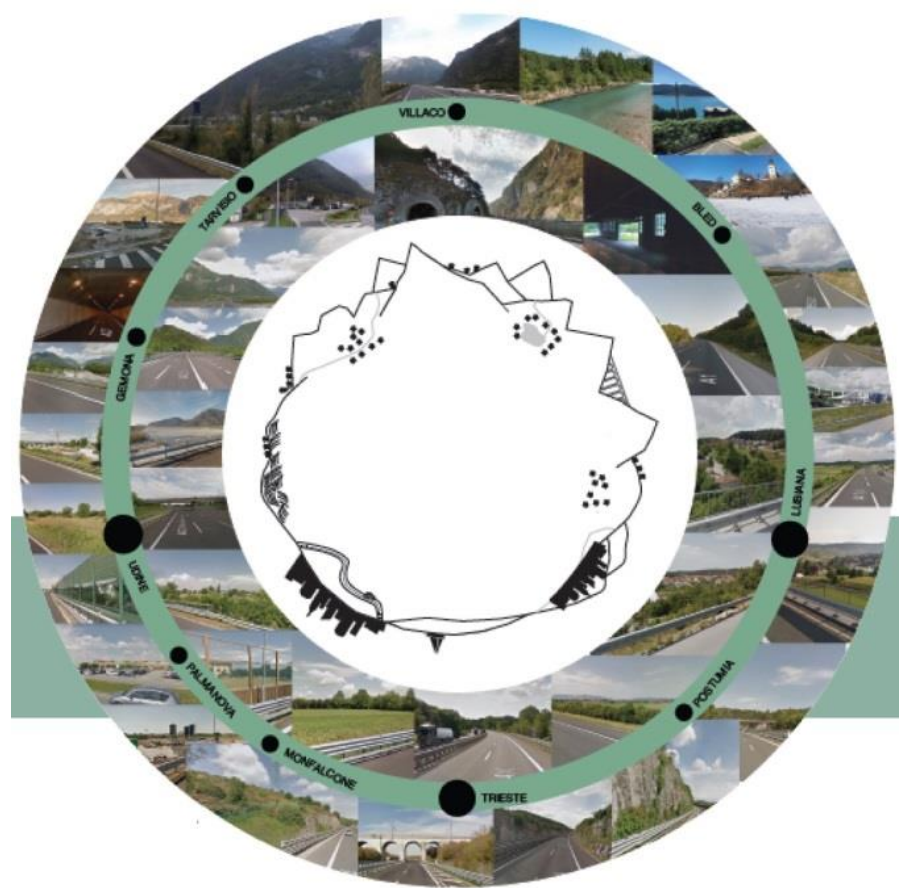

Source: Elaboration by Monica Bidoli, Matteo Savron, Elwira Wojcicka. 
Figure 20. Maps Showing the Infrastructures Used for this New Re-Shaping of the Internal Functionalities of the Territory: Highways A4 and A23 in Italy, Freeway E61 and E652 in Slovenia and Highways A2 in Austria
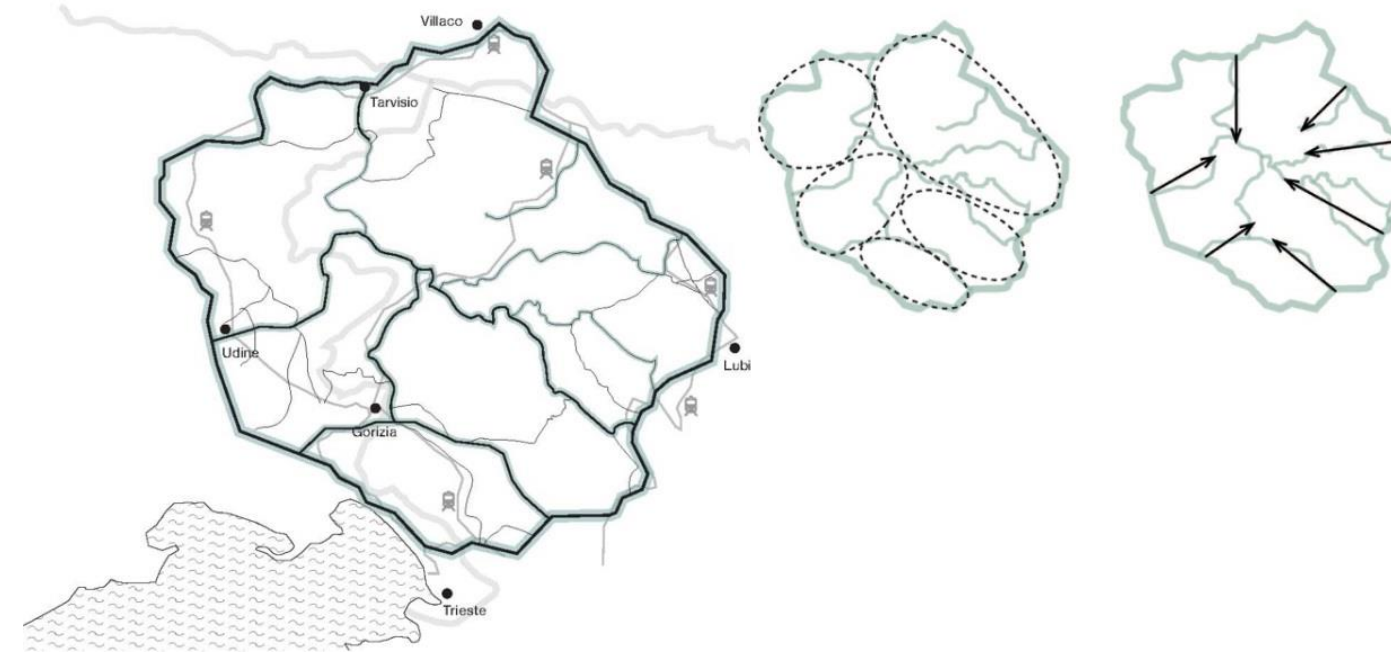

Source: Elaboration by Monica Bidoli, Matteo Savron, Elwira Wojcicka.

Figure 21. Maps Showing the Infrastructures Used for this New Re-Shaping of the External Functionalities of the Territory: New Relations of the Border Region with the Nearest External Territories, Mitteleuropa

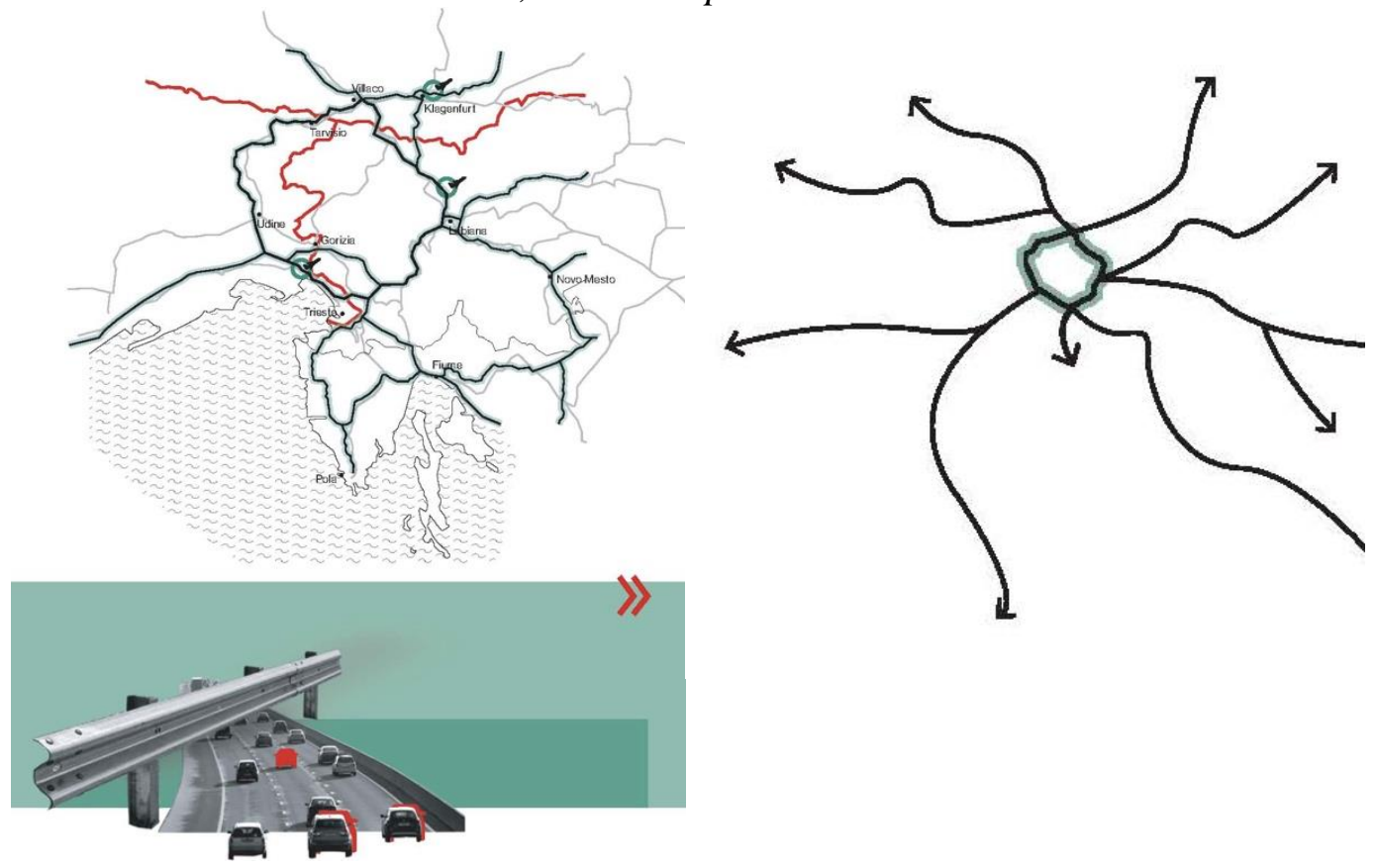

Source: Elaboration by Monica Bidoli, Matteo Savron, Elwira Wojcicka. 
Figure 22. Maps Showing the Potential Connections between Landscape-Rin with Central Europe. This Territorial Infrastructure and New Relationships Reshape the Geography of the Border, but also of the Region on which it is Located

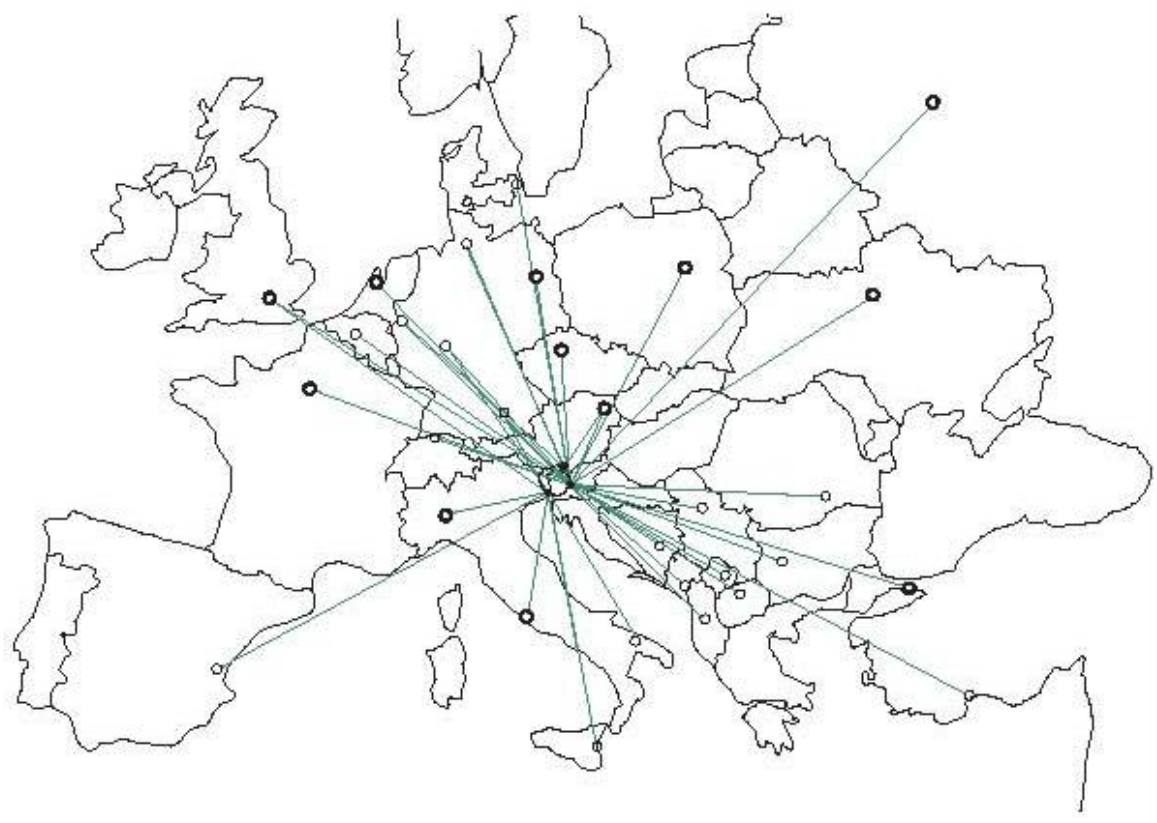

Source: Elaboration by Monica Bidoli, Matteo Savron, Elwira Wojcicka.

Figure 23. Punctual and Linear Interventions for the Completion of the Ring and the Redefinition of the Internal Region: New Cross-Border Territories

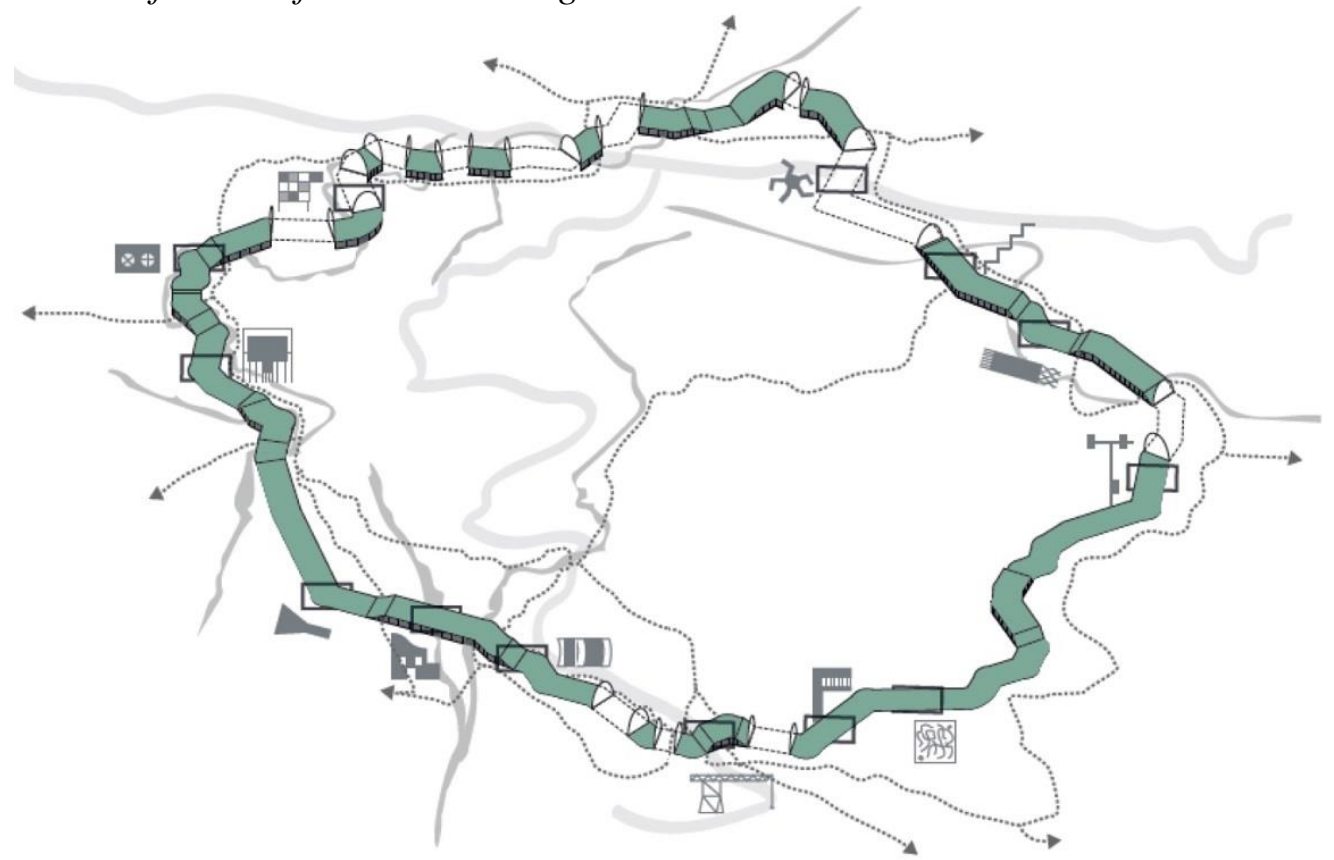

Source: Elaboration by Monica Bidoli, Matteo Savron, Elwira Wojcicka. 
Figure 24. Synthesis of the Systems that Make up the Landscape-Ring: Infrastructure Ring, Settled Housing Areas, Naturalistic Areas, Architectural and Cultural Emergencies

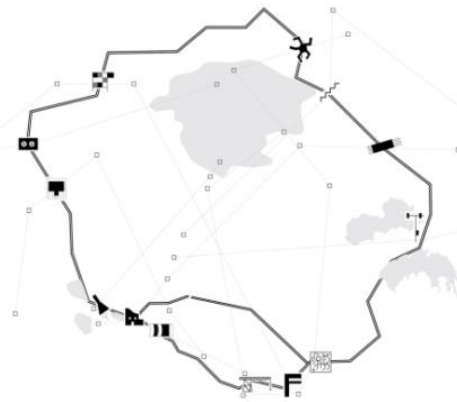

Source: Elaboration by Monica Bidoli, Matteo Savron, Elwira Wojcicka.

Figure 25. Systems Levels and Constellations of the Landscape-Ring and the Internal Border Region: 1 Relevant Sites; 2 Places of Memory; 3 Rare Public Services; 4 Flow and Mobility Services; 5 Centers of Interest; 6 Overall Constellation

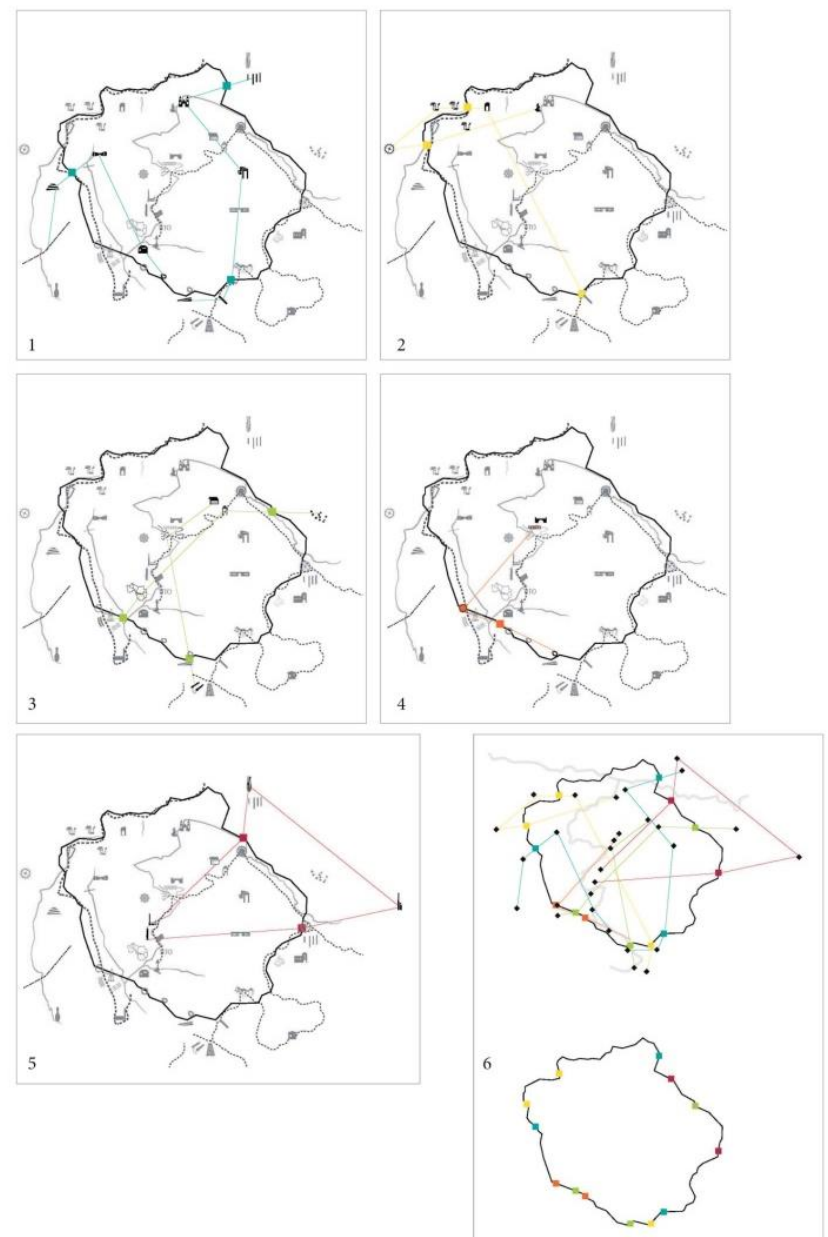

Source: Elaboration by Monica Bidoli, Matteo Savron, Elwira Wojcicka. 


\section{A New "European-Figure”: European Green Belt}

Studies and research conducted by various German Universities and the European "GreenNet" project within the "European Green Belt" program have discovered the existence of a new continental geographical system, between 2011 and 2013: the European Green Belt (Figure 26). It is a macrosystem of nature, of continental extension that develops along what was the border of the "iron curtain", and which was formed following the imposition of this border after the Second World War (Figure 27). This border, so hard and artificial, has kept away the phenomena of anthropization and waterproofing of soils and above all its buffer zone, has generally preserved incredible levels of naturalness (Figures 2829). It is paradoxical that the defense, closure and blocking wall has become over the years a system of continuity, a very important vector of naturalness and an ecological system on a European scale. This border line (the "iron curtain") has been an obstacle and a problem for more than 40 years, but today it is a resource on which the whole of Europe can review the management and organization of its environmental macro-systems according to a new naturalistic constellation, which will be able to redesign the entire continental geography. Our case study concerns a part of this European Green Belt and our research project (landscape-ring) fits into this new European geography (Figure 28).

Figure 26. European Green Belt along the Border "Cortina di Ferro"

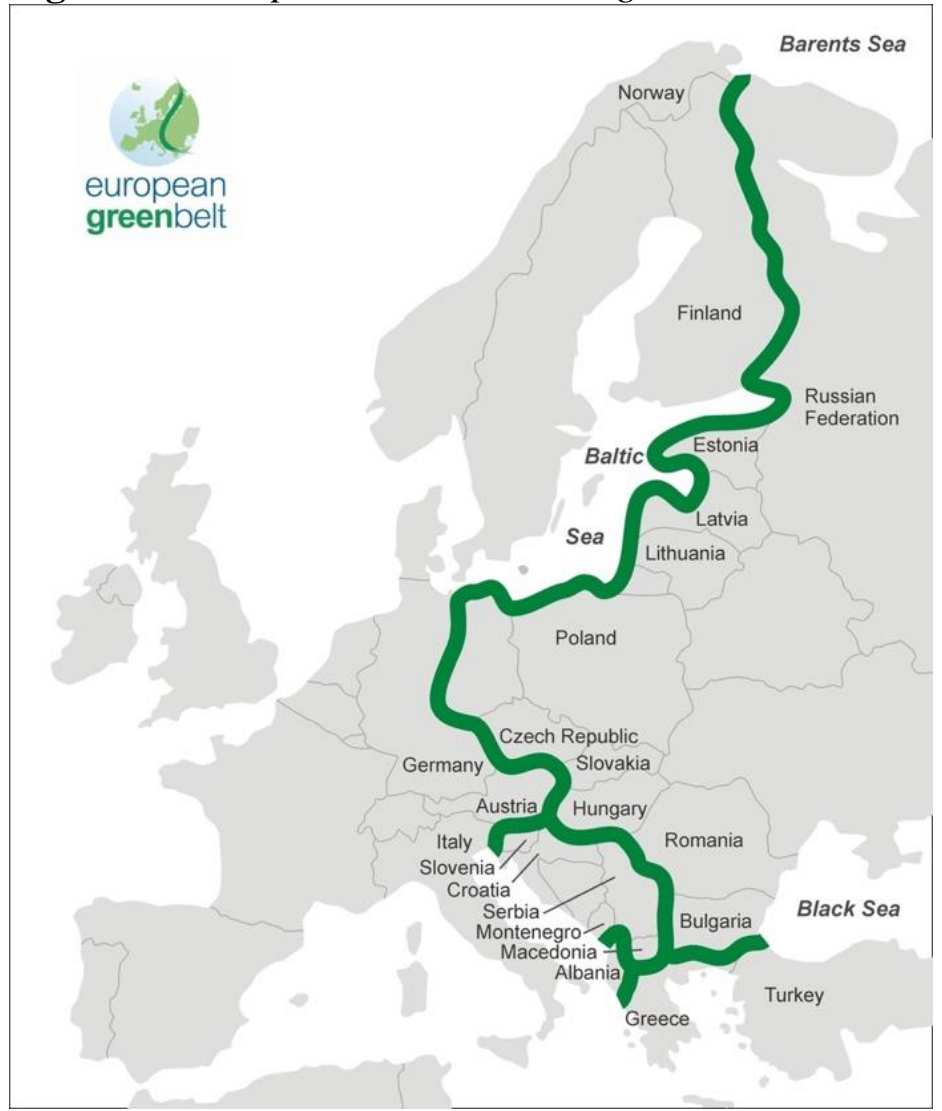

Source: Book of GreeNet $-1^{\text {st }}$ Scientific Conference. The Green Belt as a European Ecological Network, 2012. 
Figure 27. European Green Belt along the Border "Cortina di Ferro": Border Images before 1986

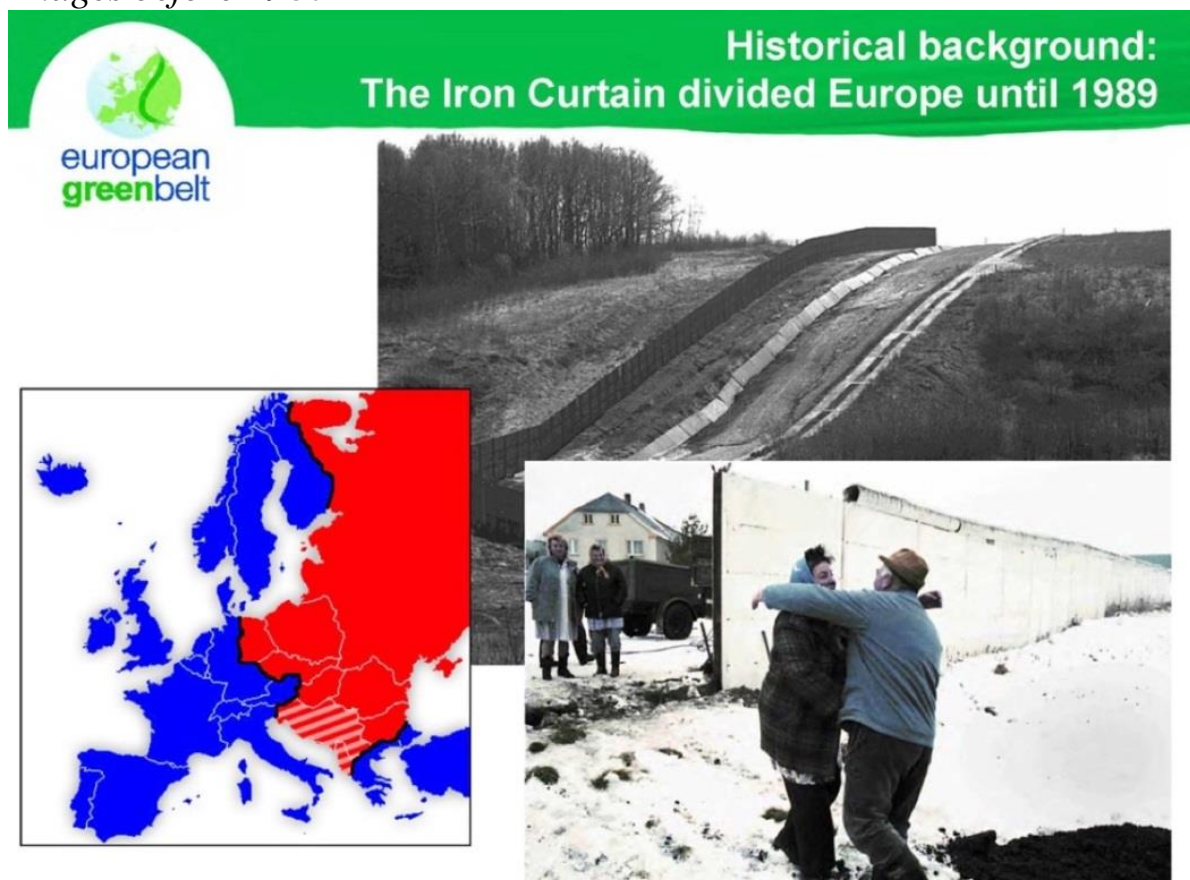

Source: Book of GreeNet $-1^{\text {st }}$ Scientific Conference. The Green Belt as a European Ecological Network, 2012.

Figure 28. European Green Belt along the Border "Cortina di Ferro": Environmental Identifications and Sites of Naturalistic Interest

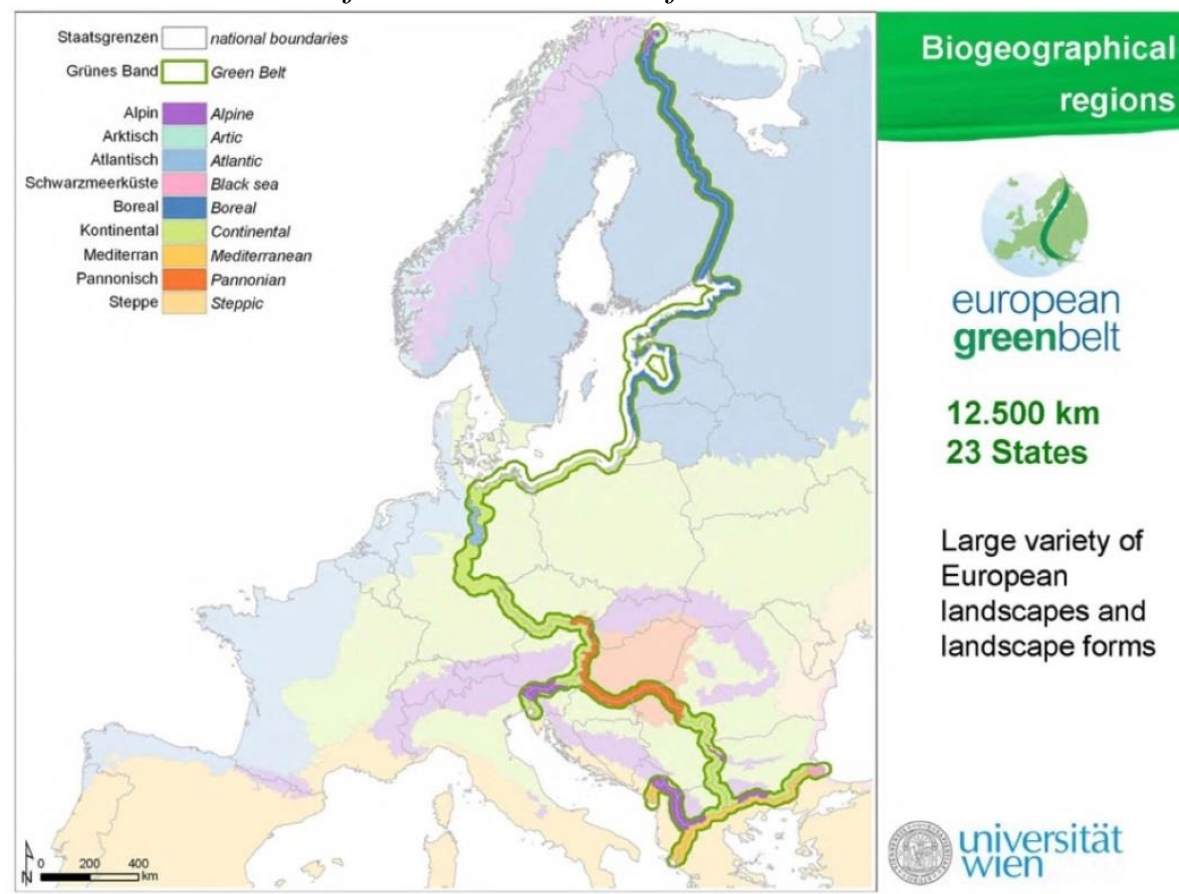

Source: Book of GreeNet $-1^{\text {st }}$ Scientific Conference. The Green Belt as a European Ecological Network, 2012. 
Figure 29. European Green Belt along the Border "Cortina di Ferro": High Biodiversity Nature Reserves along the Border
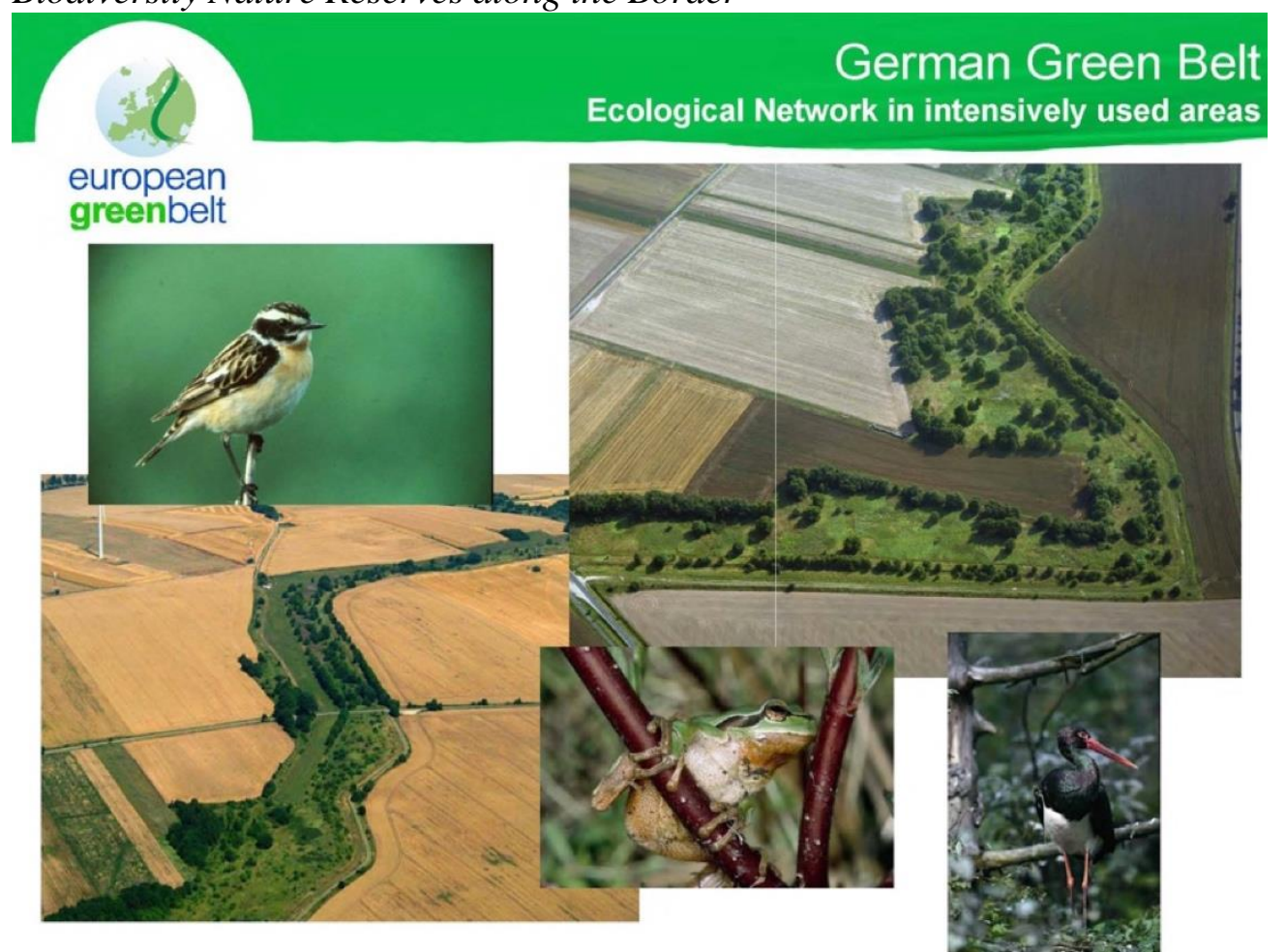

Source: Book of GreeNet $-1^{\text {st }}$ Scientific Conference. The Green Belt as a European Ecological Network, 2012.

\section{Environmental Continuity and Landscape Unity: A Cross Border Region}

In the last two centuries the region was subject to great transformations, from the administrative and political point of view. These changes have left their traces on the physical appearance of the territory as well as on the communities that inhabit it. Multiethnicity has always represented the base for the mixing of cultures and local identities. The main reason behind the dynamic balance between unity and fragmentation (Figure 30) within this region is the high level of permeability of this border, defined also as an "open border" (Valussi 1974). The paradigm of change lives within the very genetic heritage of this territory, both from the physical/morphologic and from the anthropological/cultural perspectives.

Currently three national States (Italy, Slovenia and Austria) share this border, but the region itself is a whole macro-region, unified by history, culture and geomorphology. Territorial systems overlap and shape different geographies, thus filling in the space of the border according to the "cross-border concept" (Gabrijelčič 2004) or to the idea of "transational cell" (Hudnik 2004).

The study area runs across the border regions of Friuli Venezia Giulia in Italy, Carinthia in Austria and Goriška, Gorenjsk and Obalno Kraska in Slovenia. This area has, throughout history, always been a passage towards the East. The territory has always been divided among different national States, but can be considered as 
a whole for what concerns its "common matrix", rooted in its identity of a cross border region (Jeršič 1970).

The natural systems of the territory at stake (Sistema Carta Natura, ISPRA) have a strong ecological and landscape unity (woods and forests, rivers, lakes, mountain ranges, glaciers, valleys, coast). The many small towns and five bigger centers (Tarvisio, Gorizia, Trieste, Lubljiana, Villach) located in this area, for historical reasons (such as re-definition of the borders between States after the II World War) found themselves without a real territory beside the fragmented one represented by the cross border. The geographic position as gate towards the East has favored, throughout the centuries, the creation of important transport infrastructures and of the European corridors. This allowed for a direct connection with central Europe, for what concerns trade and commerce. Thus, this "informal region", geographically located in a peripheral position, was included in a continental exchange loop, despite not being officially recognized as a whole unit from the political, administrative and economic point of view.

It seems thus relevant to point out that the fragmentation and constant change that the border has always generated in this area has paradoxically given birth to a unitary territorial entity (Figure 31), that was also partially formalized, in the last 25-30 years, as Euroregion, Alpe-Adria, Macroregion, etc., for economic, political administrative, environmental, managerial, social, landscape purposes.

Figure 30. Original Territorial Structure of Departure: The Border Analysis of Fragmentation along the Border

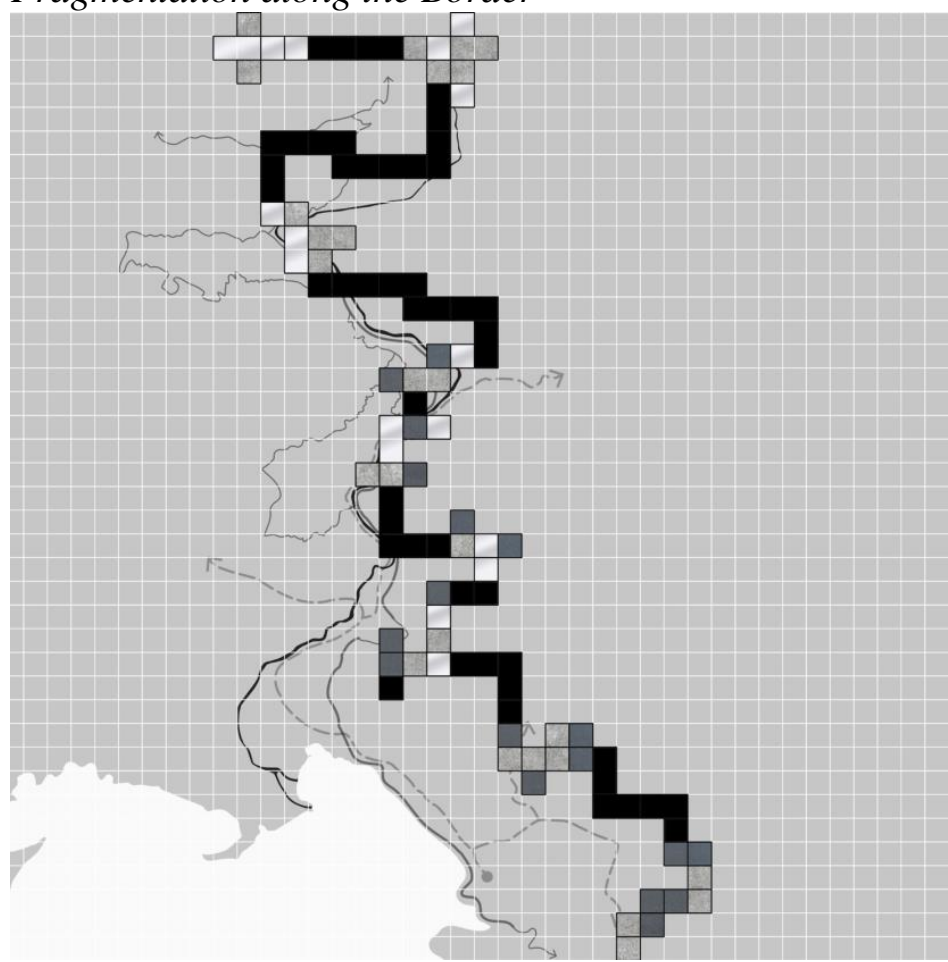

Source: Elaboration by Sofia Artico, Federica Ferrigno, Lara Slavec. 
Figure 31. New Geography Map of the Border Region Following the Re-Shaping of the Landscape-Ring

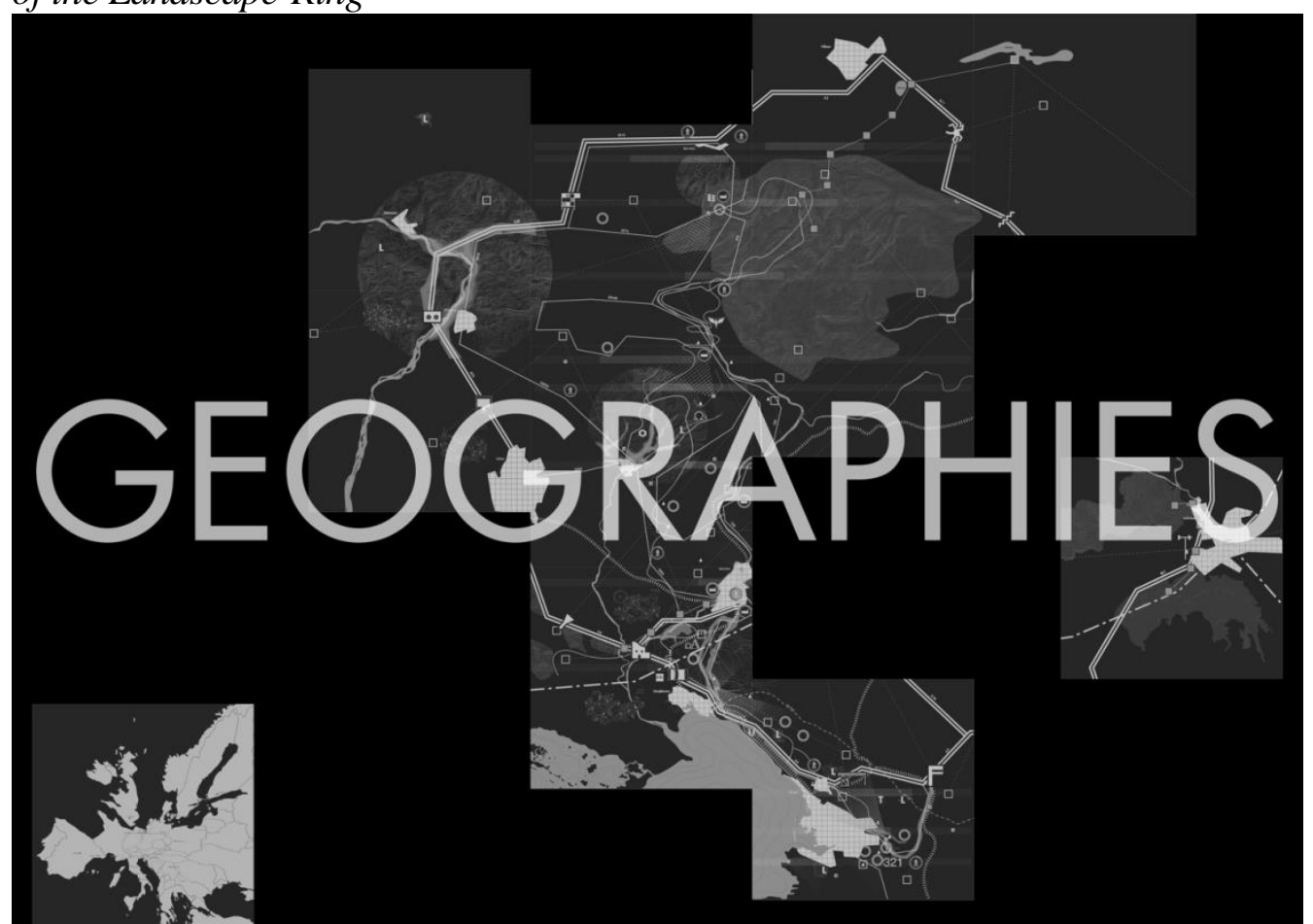

Source: Elaboration by Lorenzo Kratter, Giada Lesizza, Angela Bertoni, Virgini Fabbro, Silvia Musini, Arianna Santarsiero, Giorgio Conforto, Eleonora Di Stefano, Debora Paulin, Sofia Artico, Federica Ferrigno, Lara Slavec, Stela Guni, Giulia Piacente, Giulia Toscano, Vittoria Umani, Vlad Maricel Martinas, Semir Skenderovic, Ivan Bello Ivan, Jesku Franklind, Giacomo Caporale, Lorna Mattias, Michela Contin, Devescovi Valentina, Matteo Ros, Milisav Stankovic, Enrico Vidulich, Matteo Savron, Elwira Wojcicka Monica.

\section{Results and Conclusions}

\section{Landscape Shapes and Geography Figures}

As Corboz (1985) wrote the territory is not a given, but is always the result of many processes: "The constant mutation originates from reasons related to geology and meteorology, therefore to nature, and from reasons related to voluntary human activities" (Corboz 1985). Corboz also maintains that the inhabitants of a territory constantly erase and rewrite the ground. The continuous rewritings with geoclimatic mutations contribute together to commute the territory as an artifact, as a product. An "unfinished product", in which however, the very bond of the inhabitants is established on the possibility / necessity of transformation of reprogramming. For these reasons the territory is a project (Corboz 1985).

These topics are even more evident in the territories when the same geographical area is disputed between different ethnic groups, which elaborate different projects for the territory. The dynamism of the "territory phenomenon" is 
so evident when belonging to a topographical area is experienced as a collective experience, and therefore falls within the "imaginary of the territory".

If we use a geographical and anthropological approach together to re-read this border region, the border-landscape and the border-territory contrasts are mitigated, because the concept of limes as space prevails (Basso 2010). The very idea of boundary as space is no longer that generated by the paradigm of division, but of continuity. A continuity of landscapes and architectures that follow one another in oriented sequences along the $180 \mathrm{~km}$ of this mobile line, and around which all the inhabitants (Slovenians, Italians and Austrians) have acquired a cross-border mentality regardless of their nationality. An important question emerges from the analyses: territory-border coincidence. So if our case study is a mobile border, the territory identified with it also constantly changes the geography of this cross-border region (Figure 31).

The project-making approach towards the elaboration of a masterplan aimed at valorizing the diversities within the territory, that have always shaped the ways of life (Greiner et al. 2012) and of inhabiting (Kačič et al. 2001), the settling principles at the roots of cross border cities and villages, the ways of cultivating and managing landscape, the creation of an architectonic jargon of the border (Zanirato 1999). The masterplan investigates forms and "shapes of diversity" that are capable of enhancing unity and sense of belonging to a whole territory. The history of the city and of the territory (Benevolo 1993) remind us that great infrastructures, such as the roman aqueducts (Figure 32), the consular roads, the defensive structures of the Chinese Great (Figure 34), Wall or Hadrian's Wall (Figure 33), the pilgrimage routes (Figure 36), and more recently the European corridors have always contributed to shaping unity.

History suggests also other means for building unity (Benevolo 1993), for instance through the symbolic or functional construction, for example of bell towers (Figure 35), or landmarks, water's towers, or the development of a "unitary vision" through great landscape and perspective, rearrangements, so as theorized by Benevolo (1991) in "Capture of infinity". The shaping of the territory, especially in the Mittel-European area, has been understood and developed as management of change (Klemenčič 1979) and historically was always embodied by landscape architecture (Benevolo 1991), while finding its actual effectiveness only when codified by geography systems (Dematteis 1996).

Figure 32. Roman Aqueduct (I sec. d.c.) 
Figure 33. Hadrian's Wall (II sec. d.c.)

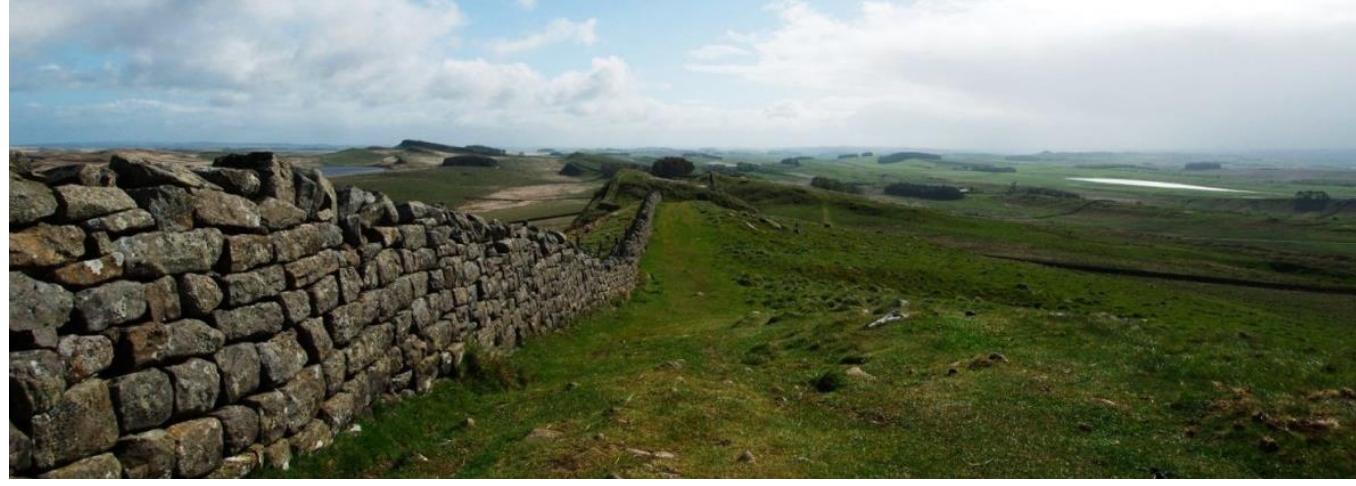

Figure 34. Great Wall of China (II sec. a.c.)

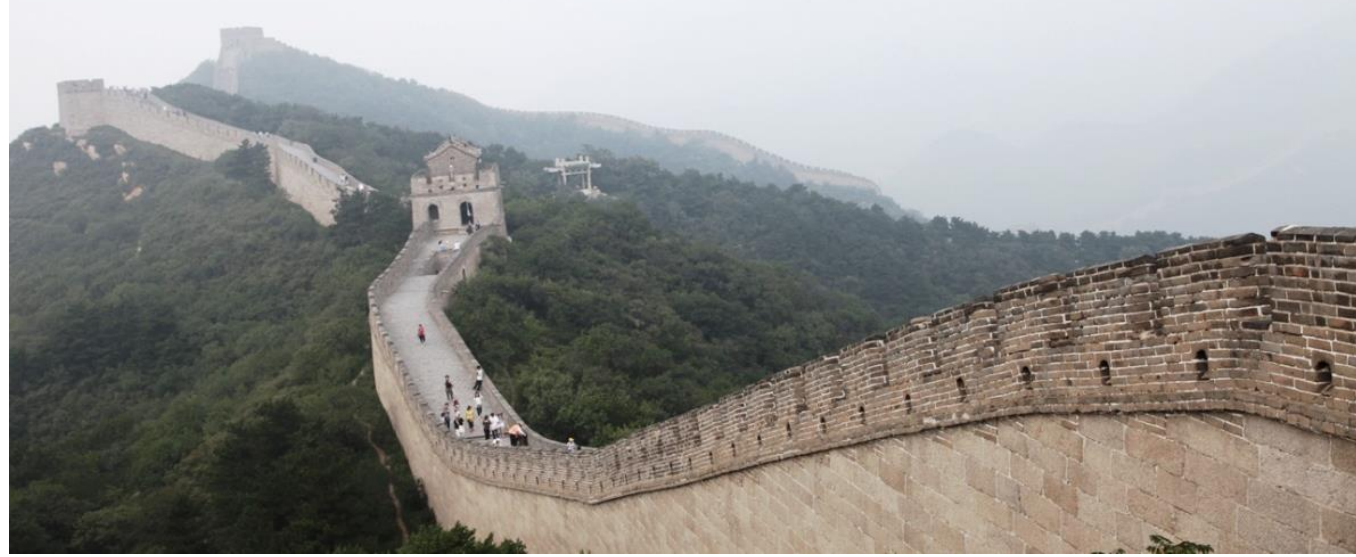

Figure 35. Series of Historical Bell Towers in the Study Area: Landscape Landmarks and Community Identity

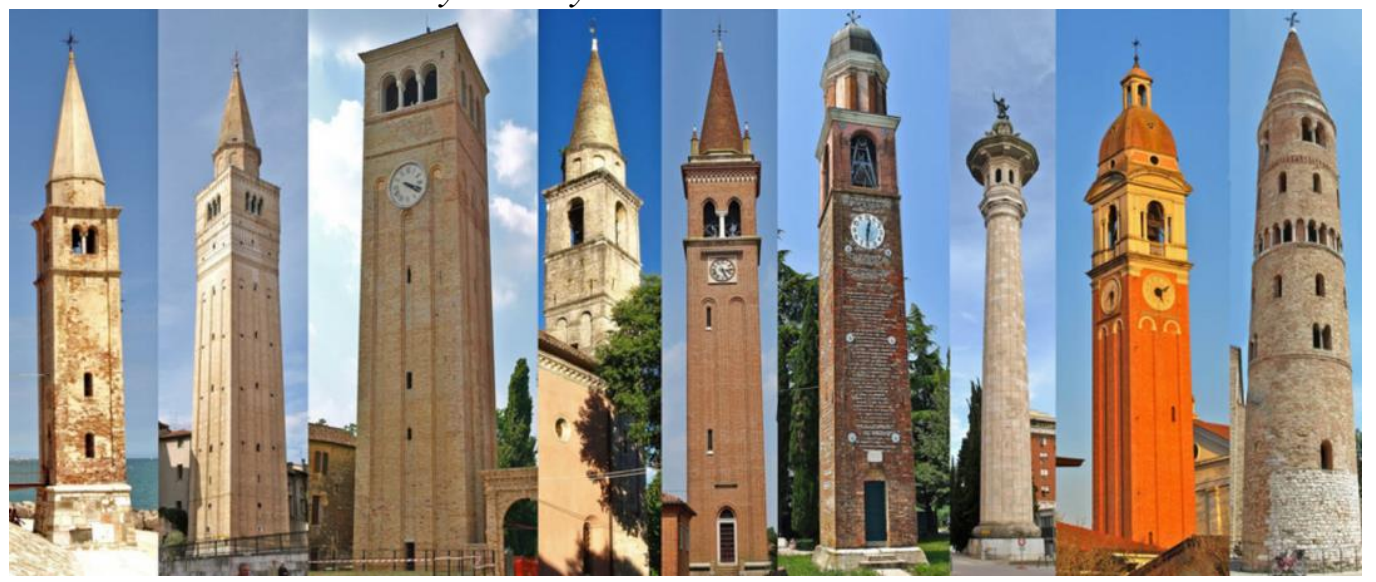


Figure 36. Monte Berico, Vicenza. Pilgrimage Route (1700)

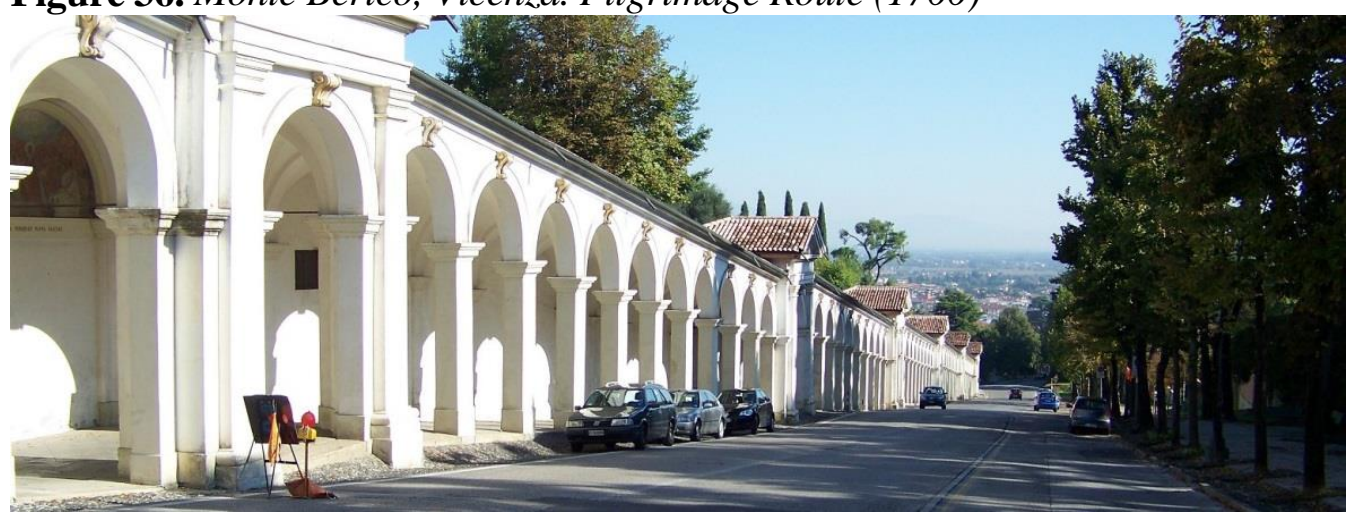

The "Itineraria Picta", the "Peuntiger Table"(Figure 37), the commercial maps of the territory of the Venetian Republic of Guadagnino, the great topographical campaigns of the Austro-Hungarian Empire or even the most recent ones of the Italian Geographical Military Institute are among the most significant examples of this semantic connection between geography, history and landscape. The role of narration in representation has always been decisive for the construction of the meaning of places (genius loci), just think of the maps and tourist guides developed by the Italian Touring Club that have strongly contributed to the creation of a culture and awareness of the landscapes.

Finally, it is worth also mentioning as an example the recent maps of the "future world order", related to communication, new media and energy (Khanna 2016).

A constant evolution of forms of the geographical space has taken place parallel to human evolution as described by Ghosn and Jazairy (2018) and to the evolution of tools and methods (Dinic 1976).

Figure 37. Peutigerian Table of Istria (XII-XIII sec.)

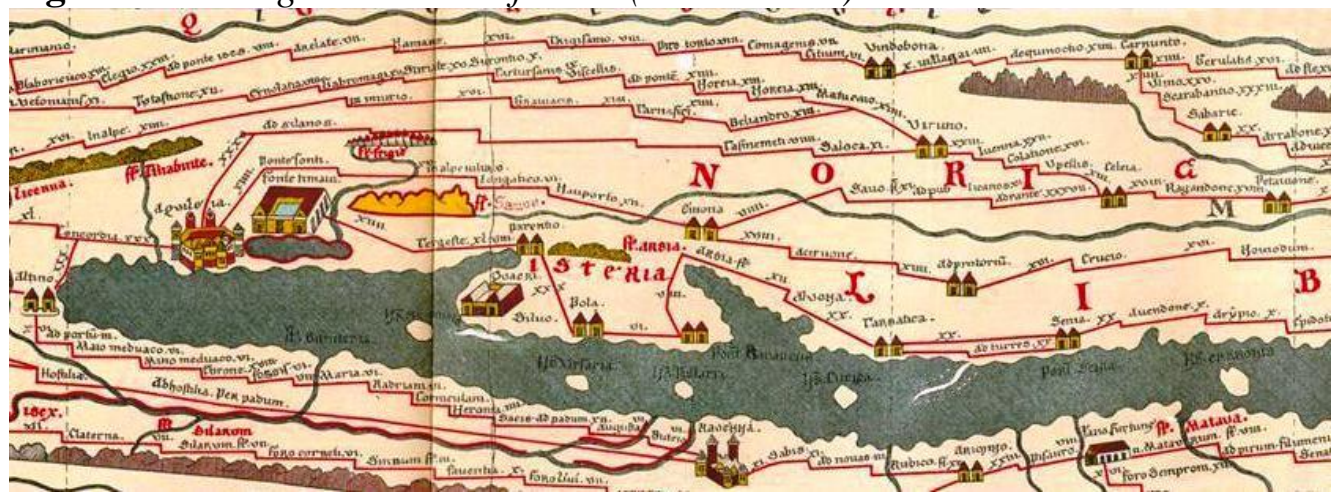

\section{Acknowledgments}

Our thanks to: Research and didactic unit: Integrated Design and Architecture Laboratory, Department of Engineering and Architecture, University of Trieste (IT) with Faculty of Architecture of Ljubljana (SLO), Year: 2018-2019. 
Coordinator and scientific manager: Giovanni Fraziano (DIA - UNITS). Team of researchers: Adriano Venudo, Thomas Bisiani, Claudio Meninno, Luigi Di Dato, Marko Verri, Stefano Simionato (DIA -UNITS), Špela Hudnik (Faculty of Architecture, University of Ljubljana). Students who have collaborated on the research team: Sofia Artico, Ivan Bello, Angela Bertoni, Monica Bidoli, Giacomo Caporale, Giorgio Conforto, Michela Contin, Valentina Devescovi, Eleonora Di Stefano, Virginia Fabbro, Federica Ferrigno, Jesku Franklind, Stela Guni, Lorenzo Kratter, Giada Lesizza, Vlad Maricel Martinas, Lorna Mattias, Silvia Musini, Matteo Ros, Debora Paulin, Giulia Piacente, Arianna Santarsiero, Matteo Savron, Semir Skenderovic, Lara Slavec, Milisav Stankovic, Giulia Toscano, Vittoria Umani, Enrico Vidulich, Elwira Wojcicka.

\section{References}

Albrecht B, Benevolo L (1992) Confini: un'ipotesi di lavoro. (Borders: a working hypothesis). In Esposizione internazionale della XVII Triennale, La vita tra cose e natura: il progetto e la sfida ambientale. Milan: Electa.

Basso S (2010) Nel confine: riletture del territorio transfrontaliero Italo-Sloveno. (In the border: reinterpretations of the Italian-Slovenian cross-border territory). Trieste: EUT.

Benevolo L (1991) La cattura dell' infinito. (The capture of infinity). Roma-Bari: Laterza.

Benevolo L (1993) Storia della città. La città contemporanea. (History of the city. The contemporary city). Roma-Bari: Editori Laterza.

Biondi N (1995) Il confine mobile. Atlante storico dell'Alto Adriatico 1866-1992. Austria, Croazia, Italia, Slovenia. (The mobile boundary. Historical Atlas of the Upper Adriatic 1866-1992. Austria, Croatia, Italy, Slovenia). Monfalcone: Edizioni della Laguna.

Bufon M (1990) Sviluppo etnico e regionale delle aree di confine: il caso degli sloveni nel Friuli-Venezia Giulia. (Ethnic and regional development of border areas: the case of Slovenians in Friuli-Venezia Giulia). Trieste: Slori.

Bufon M (1994) Per una geografia delle aree di confine. Il caso della regione transconfinaria italo slovena nel Goriziano. (For a geography of border areas. The case of the Italian-Slovenian cross-border region in the Gorizia). Rivista Geografica Italiana 101(4): 577-605.

Corboz A (1985) Il territorio come palinsesto. (The territory as a schedule). Casabella 516(Sep): 22-27.

Dematteis G (1991) Le metafore della terra: la geografia umana tra mito e scienza. (The metaphors of the earth: human geography between myth and science). Milan: Feltrinelli.

Dematteis G (1996) Immagini e interpretazioni del mutamento. (Images and interpretations of the change). In A Clementi, G Dematteis, PC Palermo (Eds), 6679. Le Forme del Territorio Italiano. Bari: Laterza.

Dematteis G, Ferlaino F (Eds) (2003) Il mondo e i luoghi: geografie delle identità e del cambiamento. (The world and places: geographies of identities and change). Torino: Istituto di Ricerche economico-sociali del Piemonte.

Di Sopra L (1967) La struttura urbanistica friulana. Analisi e prospettive. (The Friulian urban structure. Analysis and perspectives). Udine: Del Bianco Editore. 
Dinic J (1976) De la régionalisation de l'espace géographique de la Yugoslavie. (The regionalization of the geographic space of Yugoslavia). L'Espace Géographique 5(1): 49-57.

Ferrari M, Pasqual E, Bagnato A (2018) A moving border: Alpine cartographies of climate change. Columbia Books on Architecture and the City.

Gabrijelčič P (2004) Internationalisation of the border: the place of global iniziative. Development of border region in view of European integration efforts. Retrieved from: www.borderlink-is.net/Newsletter01.html.

Ghosn R, Jazairy EH (2018) Geostories: another architecture for the environment. Barcelona: Actar.

Greiner AL, Dematteis G, Lanza C (2012) Geografia umana: un approccio visuale. (Human geography: a visual approach). Torino: UTET Università.

Hudnik S (2004) Europe=City without borders. Retrieved from: www.borderlinkis.net/Newsletter01.html.

Jeršič M (1970) Odprtost mei kot dajavnik v razvoju Slovenskih obmejnih regij L'apertura dei confini come fattore di sviluppo delle regioni confinarie Slovene. (Openness as a factor in the development of Slovenian border regions - The opening of borders as a development factor for Slovenian border regions). Ljubljana: Inšt. Za geografico Univerze Ljubljana.

Kačič R, Scherl F, Kokorovec M, Vertovec M, Jarc D, Rupel A et al. (2001) Paesaggio e architettura rurale carsica. (Karst rural landscape and architecture). Ronchi dei Legionari: Ergon.

Khanna P (2016) Connectography: le mappe del future ordine mondiale. (Connectography: maps of the future world order). Rome: Fazi Editore.

Klemenčič V (1979) Urbanizzazione spaziale e minoranze etniche nel centro Europa. (Spatial urbanization and ethnic minorities in central Europe). In T De Mauro (Ed), 59-70. Conferenza Internazionale sulle Minoranze 10-14 Luglio 1974. Trieste: Atti della Conferenza, Tipografia Villaggio del Fancillo.

La Cecla F (1996) A che servono le frontiere? (What are borders for?) In A Gasparini, M Zago (Eds), 298-306. Al di là dei Nuovi Muri. L'Europa Collaborativa che Viene dalle Città di Confine, Milan: Franco Angeli.

Valussi G (1963) I tipi del paesaggio carsico. (The types of the karst landscape). Como: Società Geografica Italiana, Como.

Valussi G (Ed) (1974) Gli sloveni in Italia. (Slovenians in Italy). In Minoranze a Confronto. Contributi alla Geografia delle Minoranze Etniche sui due Lati della Frontiera Italo-Jugoslava. Udine: Pubblicazioni dell'Istituto di geografia dell'Università di Udine.

Zanini P (1997) Significati del confine. I limiti naturali, storici, mentali. (Meanings of the border. The natural, historical and mental limits). Milan: Mondadori.

Zanirato C (1999) Architettura al limite. Il limite dell'architettura, l'architettura del limite. (Architecture to the limit. The limit of architecture, the architecture of the limit). Firenze: Alinea. 